\title{
49. THE GEOLOGY AND FORMATION OF THE KING'S TROUGH COMPLEX IN THE LIGHT OF DEEP SEA DRILLING PROJECT SITE 608 DRILLING ${ }^{1}$
}

\author{
Robert B. Kidd, Institute of Oceanographic Sciences, Wormley, Surrey, United Kingdom \\ and \\ Anthony T. S. Ramsay, Department of Geology, University College of Swansea, Glamorgan, Wales, United \\ Kingdom ${ }^{2}$
}

\begin{abstract}
The continuously cored record from Deep Sea Drilling Project Site 608 has been used as a reference stratigraphy with which to compare the results of all previous dredge and rock core sampling of the King's Trough tectonic complex. Some dredge hauls from the axis of King's Trough and Palmer Ridge contain lithologic and stratigraphic units that are absent at Site 608 either because they predate basement formation at the drill site or because they fall within the range of the major upper Eocene-lower Oligocene hiatus that drilling penetrated.

Combining the data sets confirms and refines previous models of formation for the complex that involve rifting of an aseismic ridge or hot-spot trace that began its development at the Mid-Atlantic Ridge in the early Eocene (about 56 Ma). Two major intraplate tectonic events subsequently affected this ridge: (1) in the late Eocene (about $32 \mathrm{Ma}$ ), intrusion of trachytic rocks along fault planes, uplift, and explosive volcanicity near sea level; and (2) in the early middle Miocene (about $20 \mathrm{Ma}$ ), extensional rifting and subsidence of the basins and deeps of the complex through step-faulting. Palmer Ridge became isolated as a sliver of exposed deep ocean crust during this subsidence.

We refrain from discussing new plate kinematic models for the Northeast Atlantic and western Europe, but point out that, whereas the ridge uplift and intraplate volcanism was coeval with the main phase of the Pyrenean orogeny, the extension and rifting of the King's Trough complex was independent of events on the European margin. The complex does not appear to have been a plate boundary at any time.
\end{abstract}

\section{INTRODUCTION}

King's Trough comprises a 450-km-long chain of roughly parallel basins and flanking ridges, trending WNW-ESE, which is a prominent feature of the North Atlantic seafloor some $700 \mathrm{~km}$ northeast of the Azores (Fig. 1). Basins within the complex are anomalously deep when compared with the regional depth and age of ocean crust in the surrounding area, and the flanking ridges are anomalously shallow (Searle and Whitmarsh, 1978). The question of the origin of this unusual bathymetry east of the Mid-Atlantic Ridge (MAR) has attracted geophysical and geological study for over two decades, since the main basin at $44^{\circ} \mathrm{N}, 22^{\circ} 30^{\prime} \mathrm{W}$ was first described in Laughton (1965). The possibility that this intraplate complex, might, in fact, represent a former plate boundary means that it has been incorporated into various models of the evolution of the North Atlantic (LePichon and Sibuet, 1971; Williams and McKenzie, 1971; Vogt and Avery, 1974; Kristofersson, 1978; Grimaud et al., 1982 and 1983).

Kidd et al. (1982) used a GLORIA long-range sidescan sonar survey for regional geological control of a transponder-navigated dredging and coring program. Their results were used to test models for the origin of King's

\footnotetext{
${ }^{1}$ Ruddiman, W. F., Kidd, R. B., Thomas, E., et al., Init. Repts, DSDP, 94: Washington (U.S., Govt. Printing Office).

2 Addresses: (Kidd, present address) Dept. of Geology, University College of Swansea, Singleton Park, Swansea, Glamorgan SA2 8PP Wales, United Kingdom; (Ramsay) Dept. of Geology, University College of Swansea, Singleton Park, Swansea, Glamorgan SA2 8PP Wales, United Kingdom.
}

Trough, based largely upon geophysical data, that had been proposed by Searle and Whitmarsh (1978). The consensus of these investigations was that the tectonic complex developed by a combination of initial spreading from an elevated part of the mid-ocean ridge ("hot spot") and subsequent rifting, extension, and subsidence of the WNW-ESE trending ridge that had formed.

There was no continuous stratigraphic record in the area that could be brought together with the dredge and rock core data. No matter how precisely located this sampling program had been, there were major stratigraphic uncertainties to hamper the interpretation and construction of tectonic models (Kidd et al., 1982).

In the DSDP Leg 94 paleoenvironmental transect, there was a requirement for a site located astride the southernmost penetration of polar water during the glacial periods. This requirement brought with it the opportunity to drill to basement on the south flank of the King's Trough complex (Fig. 2).

In this chapter, we bring together the results of DSDP Site 608 with the previous dredge and rock core data, using the same biostratigraphic time scales of Berggren, Kent, and Flynn (1985a) and Berggren, Kent, and Van Couvering (1985b). We will look for the temporal and spatial amplification of the regional geology that the earlier sampling can now provide. We will consider some of the postdrilling results of other studies in this volume that deal with Site 608 as well as some findings of concentrated geophysical and geologic studies on the south flank of the complex that derive from a program of feasibility studies for high-level radioactive waste disposal (Kidd et al., 1983). 


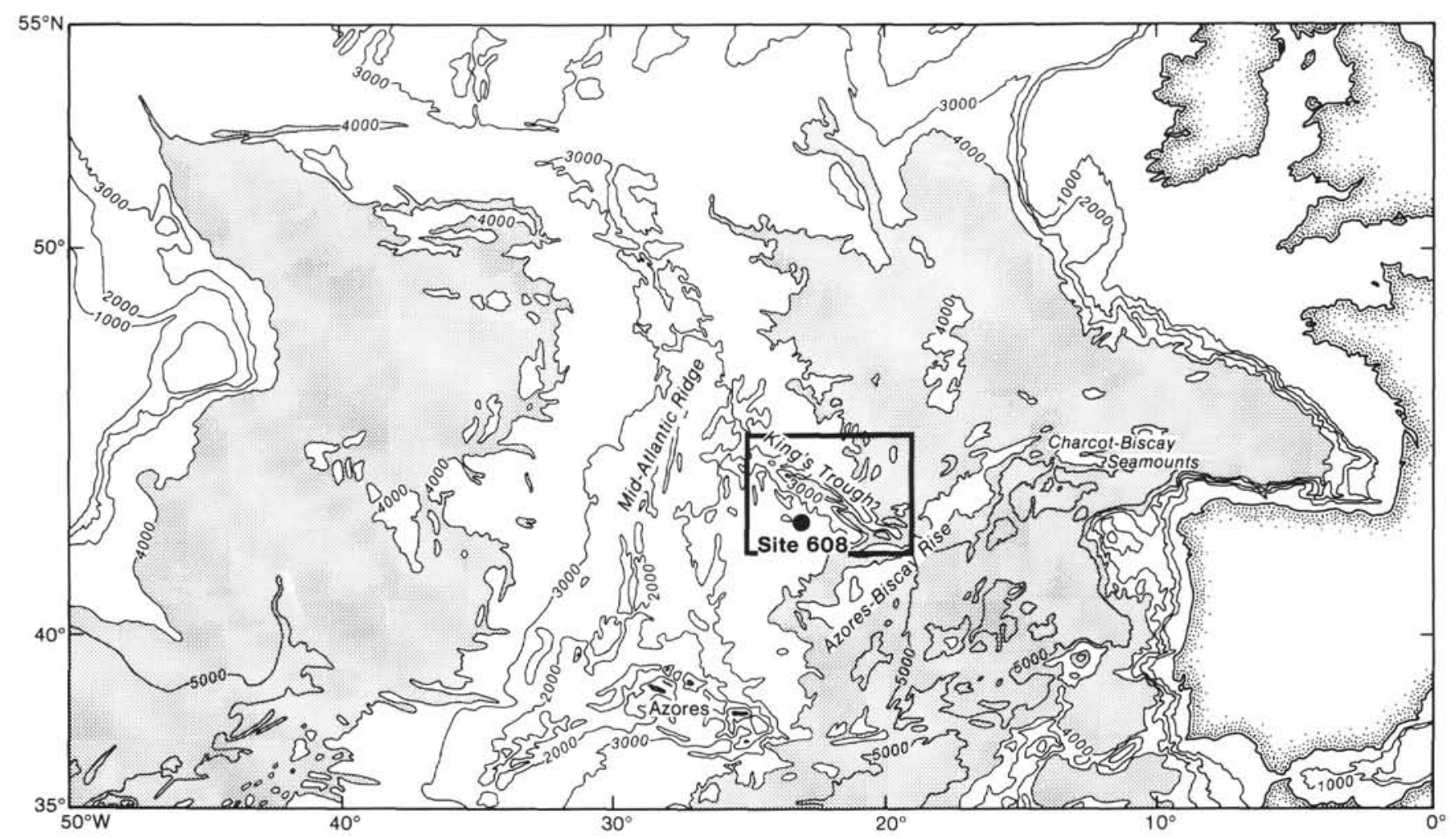

Figure 1. Location of the King's Trough tectonic complex and DSDP Site 608. North Atlantic bathymetry in corrected meters.

The major question that we address is this: How does the model favored on the basis of previous sampling and geophysical studies (Kidd, et al., 1982; Searle and Whitmarsh, 1978) stand the test of an almost complete regional geologic record?

\section{BATHYMETRIC SETTING}

The 1977 GLORIA sidescan survey provided a planview mosaic that allowed the refinement of previous maps of the King's Trough area (Kidd et al., 1982); more recent geophysical cruises conducted on the northern and southern flanks of the complex provided improved bathymetry, which has been incorporated in the previously unpublished bathymetric map in the back pocket of this volume (see back-pocket Figs. 3 and 4). Three major deeps are outlined by the $4000-\mathrm{m}$ isobath:

1. the main basin, approximately between $21^{\circ} \mathrm{W}$ and $24^{\circ} \mathrm{W}$, whose flat turbidite-sedimented floor is at about $4500 \mathrm{~m}$ depth;

2. a southern basin, between about $21^{\circ} 20^{\prime} \mathrm{W}$ and $19^{\circ} 30^{\prime} \mathrm{W}$, that in the west is over $4000 \mathrm{~m}$ deep but deepens southwestward to over $5200 \mathrm{~m}$, becoming Freen Deep; and

3. Peake Deep that lies between about $19^{\circ} 20^{\prime}$ and $20^{\circ} 10^{\prime}$ and is floored with turbidites at around $5200 \mathrm{~m}$ depth (Davies and Jones, 1971).

The flanking ridges within the complex are best outlined by the $2400-\mathrm{m}$ contour. The most notable ridge relief is on both sides of the main basin, with Antialtair Seamount on the south side and ridge summits at around $1800 \mathrm{~m}$ on the north side. Seismic sections of the complex show the faulted and terraced nature of internal walls of the flanking ridges and the more tilted aspect of the ridges to the north and south (Fig. 2). Faulting and terracing is also characteristic of the flanks of Palmer Ridge (Fig. 5). The ridge summit is in the 3000-m depth range, but its relative relief makes it a significant feature between Peake and Freen deeps (Matthews et al., 1969).

Sediment thicknesses within the major basins are in excess of $1 \mathrm{~km}$ and dredge and rock core sampling has concentrated on the fault scarps of the flanking ridges (Fig. 2).

DSDP Site 608 was located on the south flank of the complex $\left(42^{\circ} 50.2^{\prime} \mathrm{N} ; 23^{\circ} 05.2^{\prime} \mathrm{W}\right)$, about 50 nautical miles (n. mi.) southwest of Antialtair Seamount and in 3534 $\mathrm{m}$ of water. The south and north flanks of the King's Trough complex make up part of the $40^{\circ} \mathrm{N}-47^{\circ} \mathrm{N}$ MidAtlantic Ridge flank province (Fig. 1) that is recognized as generally $1 \mathrm{~km}$ shallower than it should be if it had subsided normally from the spreading axis (Searle and Whitmarsh, 1978; Parsons and Sclater, 1971). The south flank topography is rugged with a strong linear element trending subparallel to the MAR. Basins and ridges are largely basement-controlled and a number of large seamounts and fracture zones occur (Kidd et al., 1983). Sediment thicknesses vary greatly across the south flank but there is a general increase in thickness along with age of crust towards the southeast (Fig. 6). Little basement outcrop is present except around a seamount in the southwest.

\section{SAMPLING HISTORY}

Prior to Leg 94, all of the rock sampling of the King's Trough complex had been conducted on four Discovery 

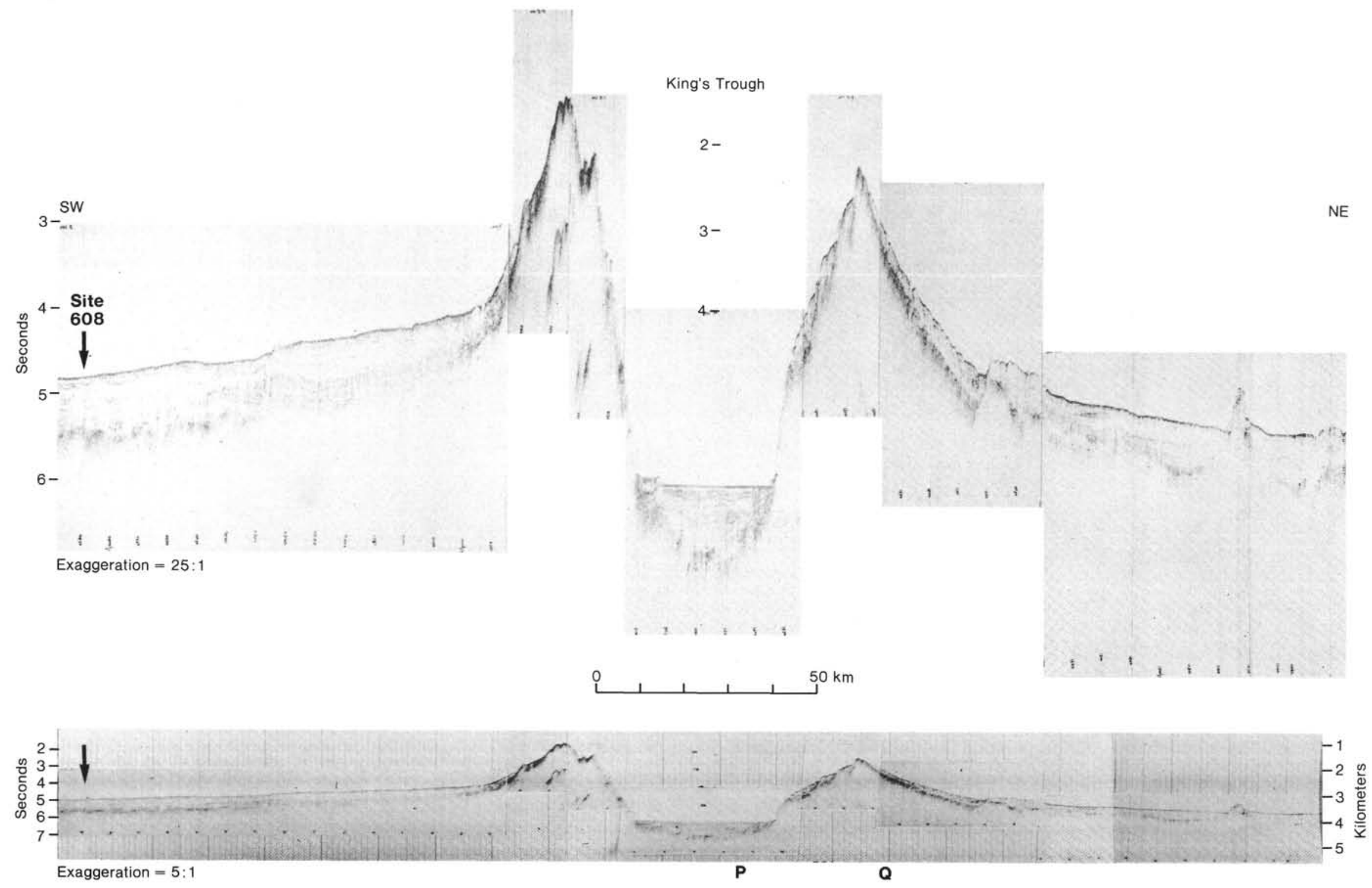

Figure 2. SW-NE seismic reflection profile of the King's Trough complex from $42^{\circ} 45^{\prime} \mathrm{N}, 23^{\circ} 05^{\prime} \mathrm{W}$ (SW) to $44^{\circ} 55^{\prime} \mathrm{N}, 21^{\circ} 05^{\prime} \mathrm{W}$ (NE) showing the location of Site 608 . The lower illustration shows the record photographically stretched to reduce vertical exaggeration. Note the step-faulted trough walls and the thick, layered (turbidite) sediments in the trough axis. $\mathrm{P}$-Q indicates the part of this profile that spans the "King's Trough Axis" dredge and core sampling area shown in Figure 8. 


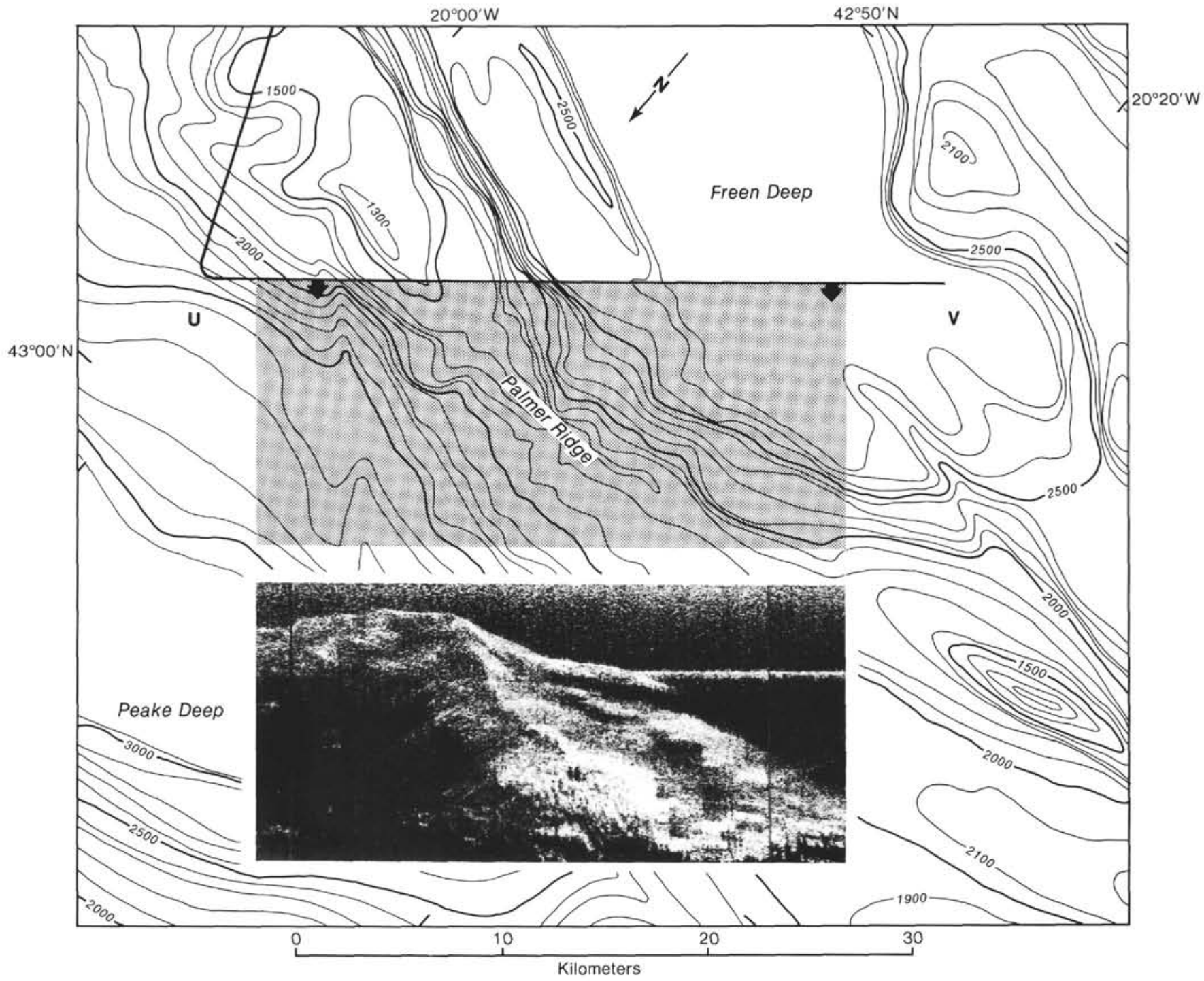

Figure 5. Detailed chart of the Palmer Ridge area with superimposed GLORIA sidescan sonar coverage of the shaded area between U and V (after Laughton, 1982). Note that the bathymetric contours are in fathoms and the view is towards the southeast.

cruises $(1965,1966,1970,1977)$, one Vema cruise (1969), and one Chain cruise (1977).

The first two Discovery cruises concentrated on sampling Palmer Ridge, and recovered igneous and metamorphic basement as well as overlying Tertiary sedimentary rocks (Cann and Funnell, 1967; Ramsay, 1970; Cann, 1971). The 1970 and 1977 Discovery cruises worked mainly on the flanking ridges of the main (axis) basin; the latter was the combined GLORIA/transponder-navigated sampling exercise that attempted to sample identifiable outcrops (Kidd et al., 1982).

Eleven Chain dredge hauls that contained igneous rocks were analyzed petrographically by Stebbins and Thompson (1978). The samples again came from the scarps flanking the main basin or axis and were alkali basalts, tuffs, diorites, and gabbros. Subsequent analyses did provide strong evidence of intraplate volcanism, but no results were reported on the stratigraphy of any sedimentary rocks.

Only preliminary shipboard descriptions are available for the two Vema hauls. Comparison of the rock types with those recovered by Discovery suggests that little, if any, in situ material was present in the Vema hauls.

All of the Discovery dredge hauls were carefully sorted using the criteria for identification of glacial erratics developed for Kidd et al. (1982) and outlined in detail in Huggett and Kidd (1984/5). We feel confident that the dredge samples used here for comparison with Site 608 are in situ.

Figure 7 shows the distribution of the dredge sampling within the complex. Below, we examine the stratigraphical data from these key locations and compare these data with Site 608 .

\section{STRATIGRAPHICAL DATA}

\section{Palmer Ridge}

Before drilling at Site 608 took place, the rock dredge and core samples recovered from detailed sampling at Palmer Ridge provided the most complete sequence of Tertiary sediments from the King's Trough complex. The location of the dredge and core stations and the nature 


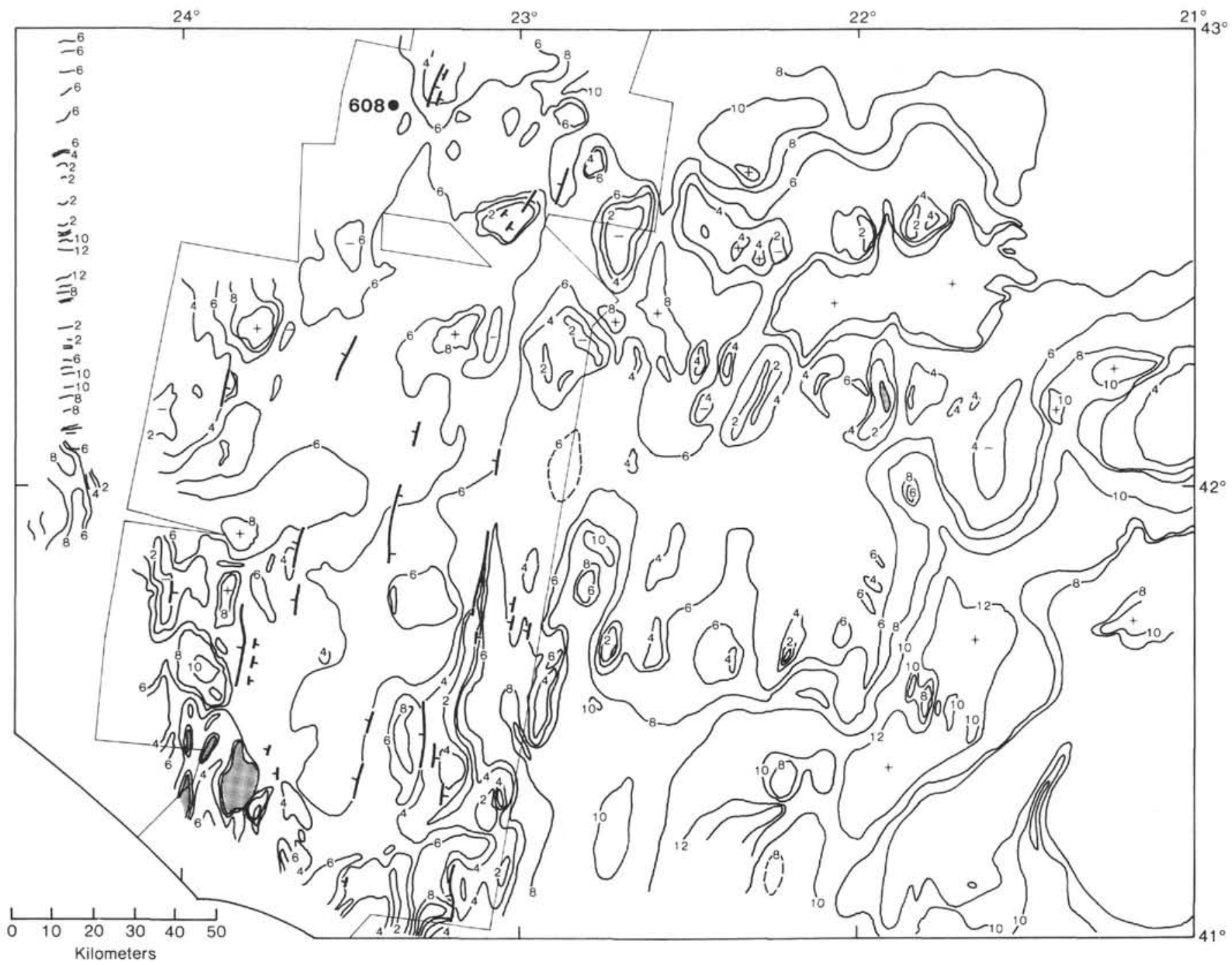

Figure 6. Sediment thicknesses in the Mid-Atlantic Ridge flank province immediately south of King's Trough; isopachs in 200-m/s intervals uncorrected two-way traveltime; thin box outline shows GLORIA sidescan sonar coverage that detected faults and outcrop (stippled); mapping by C. Jacobs for Kidd et al. (1983).

of the samples recovered are summarized in Table 1. Most stratigraphic information derives from nannofossil, foraminiferal, and zeolitic chalks. Other in-situ rock types present were basalts, amphibolites, serpentinites, gabbros, and volcanic ashes. The relationship between the dredge stations and the bathymetry of the Palmer Ridge detailed sampling area is shown in Figure 8.

The detailed stratigraphy of the Palmer Ridge samples summarized in Figure 9 is based on a re-examination of biostratigraphical data published by Ramsay (1970). These data were revised to accomodate more recent advances in nannofossil stratigraphy (Martini, 1971; Bukry, 1973, 1975, 1981; Okada and Bukry, 1980), and the updated information was related to the time scales of Berggren et al. $(1985 \mathrm{a}, \mathrm{b})$. The range of absolute ages obtained from the dredged amphibolites is also included in Figure 9.

The lithologic sequence inferred from the dredge hauls by Ramsay (1970) began with lower Eocene zeolitic chalks, basalts, and amphibolites. One rock core, D5971, recov- ered zeolitic chalks of the same age that were strongly jointed with slickensides. The jointing was thought to be an original feature of the core and some of the dredge rocks. Middle and upper Eocene samples were zeolitic chalks but with unaltered volcanic ash material. One dredge haul contained some Oligocene and lower Miocene chalks in which little volcanic material was present. Amphibolites of approximately equivalent age were associated with these chalks and also some fragments of serpentinite. Cann (1971) later found these younger amphibolites to be retrograded by metamorphism. An assemblage of chalk rocks of middle to late Miocene age was next in the inferred sequence, and almost all of the samples were strongly jointed. Winnowed foraminiferal chalks of Pliocene age completed the sequence.

Cann and Funnell (1967) made elegant use of the paleontological data then available and the absolute ages from the two assemblages of amphibolites to interpret the geology of Palmer Ridge. They characterized Palmer Ridge as a serpentinite ridge, a sliver of exposed deep 


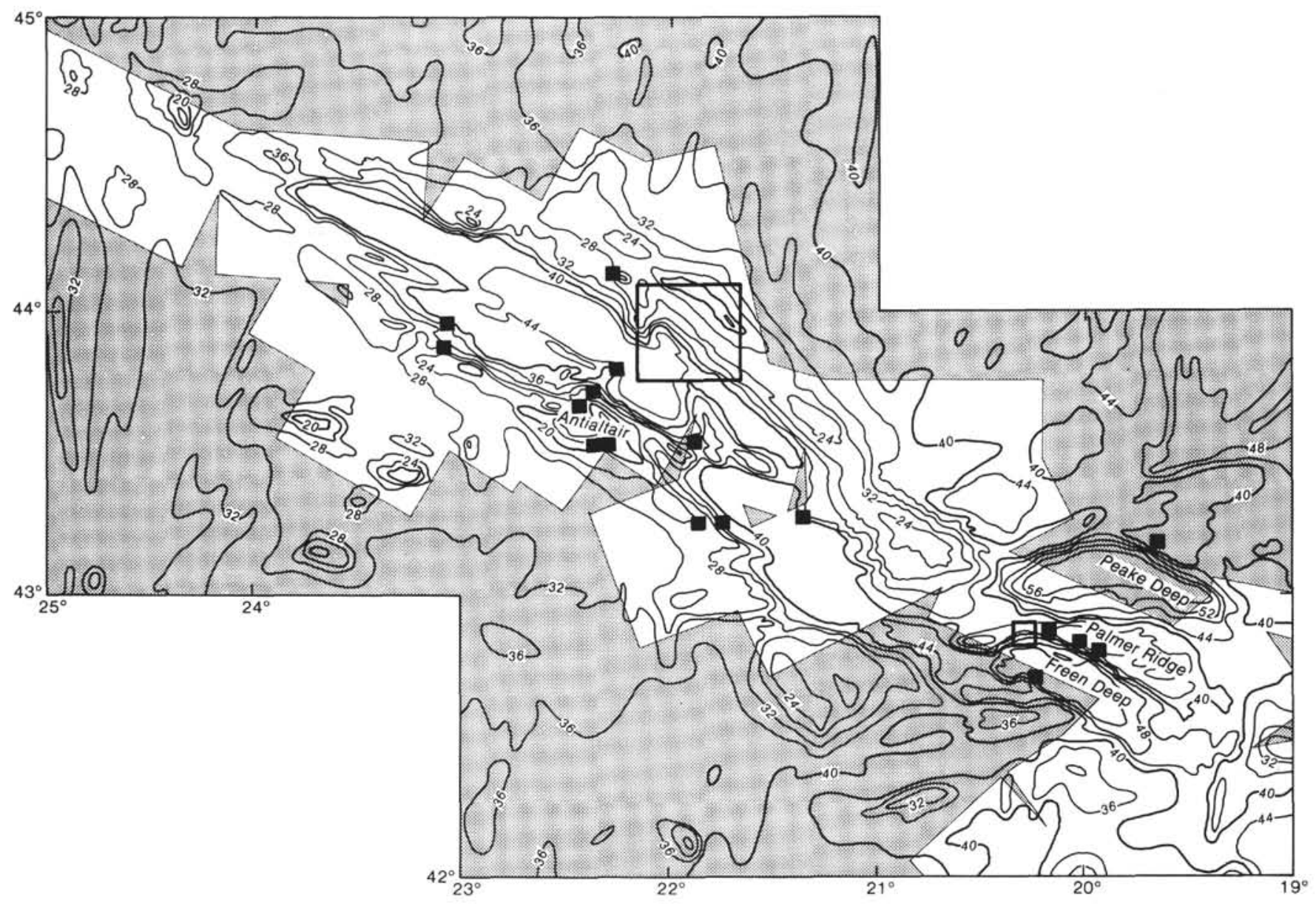

Figure 7. Location of dredge stations within the King's Trough complex: bathymetry in 400-m intervals (corrected); unshaded area represents GLORIA sidescan sonar coverage. Large rectangle defines the "King's Trough Axis" detailed sampling area (Kidd et al., 1982); see Figure 10. Small rectangle defines the "Palmer Ridge" sampling area (Ramsay, 1970); see Figure 8. Solid squares record all dredge stations outside these areas. (Site 608 is located just off the map at $42^{\circ} 50.2^{\prime} \mathrm{N}, 23^{\circ} 05.2^{\prime} \mathrm{W}$.)

Table 1. Palmer Ridge: list of dredge and rock core stations used in this report. ${ }^{\mathrm{a}}$

\begin{tabular}{|c|c|c|c|c|}
\hline Station & Latitude & Longitude & $\begin{array}{c}\text { Water } \\
\text { depth }(m)\end{array}$ & Comments \\
\hline \multicolumn{5}{|l|}{ Dredge } \\
\hline DS608 & $42^{\circ} 52.0^{\prime} \mathrm{N}$ & $20^{\circ} 16.5^{\prime} \mathrm{W}$ & $4276-3932$ & $\begin{array}{l}\text { Nannofossil chalk and volcanic } \\
\text { ash }\end{array}$ \\
\hline D5619 & $42^{\circ} 54.0^{\prime} \mathrm{N}$ & $20^{\circ} 15.0^{\prime} \mathrm{W}$ & $3255-3146$ & Foraminiferal chalk \\
\hline D5623 & $43^{\circ} 07.5^{\prime} \mathrm{N}$ & $19^{\circ} 39.5^{\prime} \mathrm{W}$ & $3658-3988$ & Basalt and nannofossil chalk \\
\hline DS626 & $42^{\circ} 50.8^{\prime} \mathrm{N}$ & $19^{\circ} 59.5^{\prime} \mathrm{W}$ & $2573-2487$ & Foraminiferal chalk \\
\hline D5968 & $42^{\circ} 50.3^{\prime} \mathrm{N}$ & $20^{\circ} 12.2^{\prime} \mathrm{W}$ & $5336-4662$ & $\begin{array}{l}\text { Serpentinite and zeolitic nanno- } \\
\text { fossil chalk }\end{array}$ \\
\hline D5969 & $42^{\circ} 55.0^{\prime} \mathrm{N}$ & $20^{\circ} 11.5^{\prime} \mathrm{W}$ & $3654-3116$ & Zeolitic nannofossil chalk \\
\hline D5977 & $42^{\circ} 54.2^{\prime} \mathrm{N}$ & $20^{\circ} 15.9^{\prime} \mathrm{W}$ & $3244-3155$ & Foraminiferal chalk \\
\hline D5981 & $42^{\circ} 51.5^{\prime} \mathrm{N}$ & $20^{\circ} 16.5^{\prime} \mathrm{W}$ & $4556-4513$ & $\begin{array}{l}\text { Gabbro, nannofossil chalk, and } \\
\text { zeolitic nannofossil chalk }\end{array}$ \\
\hline D5983 & $42^{\circ} 54.4^{\prime} \mathrm{N}$ & $20^{\circ} 13.4^{\prime} \mathrm{W}$ & $3244-3069$ & $\begin{array}{l}\text { Serpentinite and foraminiferal } \\
\text { chalk; erratics }\end{array}$ \\
\hline D5985 & $42^{\circ} 52.0^{\prime} \mathrm{N}$ & $20^{\circ} 12.4^{\prime} \mathrm{W}$ & $4599-4080$ & $\begin{array}{l}\text { Amphibolites, serpentinite, and } \\
\text { nannofossil chalk }\end{array}$ \\
\hline \multicolumn{5}{|l|}{ Core } \\
\hline D5971 & $43^{\circ} 01.4^{\prime} \mathrm{N}$ & $20^{\circ} 07.0^{\prime} \mathrm{W}$ & 5300 & $\begin{array}{l}143 \mathrm{~cm} \text { of nannofossil ooze } \\
\text { overlying } 37 \mathrm{~cm} \text { of nanno- } \\
\text { fossil chalk and zeolitic clay }\end{array}$ \\
\hline
\end{tabular}

basement. Despite our revised biostratigraphy, their broad conclusion appears still justified: that the crust at Palmer Ridge formed at the crest of the late Paleocene MidAtlantic Ridge (at approximately $60 \mathrm{Ma}$ ) and that a new ridge formed during the Oligocene. We suggest later in this chapter that Palmer Ridge could have developed because subsidence formed Peake and Freen deeps on either side of it, rather than through uplift of an intervening piece of crust, as these authors hypothesized.

\section{King's Trough Axis}

Kidd et al. (1982) used information derived from igneous and sedimentary rocks at the dredge and rock core stations flanking the main basin. We term this location "King's Trough Axis" for convenience of discussion. The locations of the stations and the nature of the samples recovered are summarized in Table 2 . Nannofossil chalks in the hauls were accompanied by basalts, hyaloclastite, trachytes, and volcanic tuffs and ashes. The chalks provide a record of Tertiary deposition almost as complete as that obtained for Palmer Ridge. Because of bottom transponder navigation during sampling, sites can be related to outcrops identified on GLORIA sonographs (Fig. 10). 


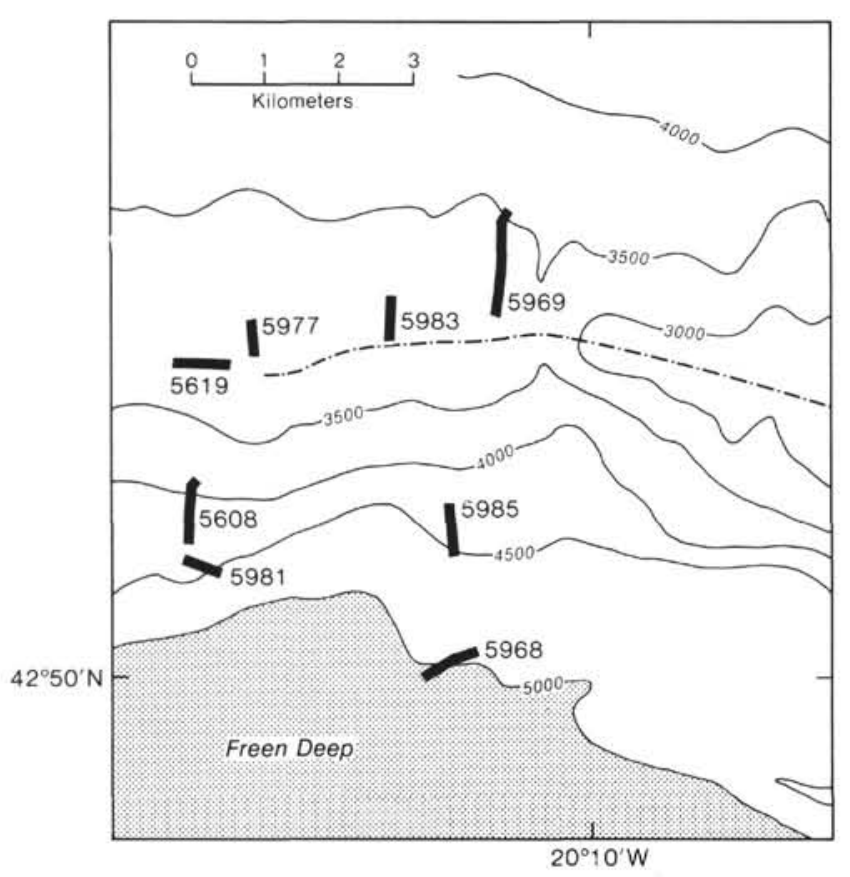

Figure 8. Palmer Ridge detailed sampling area: Bathymetry in corrected meters and details of ship's traverses at dredge stations superimposed as solid heavy lines with the station numbers. The crest of the ridge is indicated by the dashed and dotted line, the stippled area defines the floor of Freen Deep (depths greater than $5000 \mathrm{~m}$ ).

Details of the biostratigraphy of cored and dredged Tertiary sediments now placed in the Berggren et al. $(1985 a, b)$ time scales for Paleogene and Neogene are summarized in Figure 11. A number of refinements to the biostratigraphic ages determined for Kidd et al. (1982) were necessary.

The sequence inferred from the King's Trough Axis dredge hauls and rock cores (Kidd et al., 1982) begins with basalts and hyaloclastites, which we assume were derived from submarine mid-ocean basalt eruptions, and nannofossil chalks. The K-Ar ages of the dredged basalts $(52 \pm 6 \mathrm{Ma})$ and the magnetic age of basement recorded for this location (Anomaly 21, about $50 \mathrm{Ma}$ ) seem compatible. The age of the oldest sediment recovered, in dredge haul D9572, is uncertain because of the poor preservation of the fossil nannoflora. One readily identifiable species, Ellipsolithus macellus, ranges from NP3 to NP12 (Haq, 1983), and it is assumed that the sediments at station 9572 preserve the latter end of its range. However, the youngest record of this species at $54 \mathrm{Ma}$ is older than the magnetic age of basement suggested for this location. An upper Eocene volcanic-glass-rich nannofossil chalk recovered in rock core D9567 was jointed and slickensided and contained patches of zeolitic ash.

$\mathrm{K}$-Ar ages are available for trachytes in the dredge hauls. They provide evidence of a period of intraplate volcanism at around $32 \mathrm{Ma}$, which would place them in the early Oligocene. Volcanic tuffs and ashes were recovered in three of the dredge hauls. These tuffs and ashes proved impossible to date because of alteration of carbonate and glass components, but clasts of unaltered trachyte made up a significant component of the tuffs. Thus they are inferred to be slightly younger than or coeval with the trachytes.
Lowermost Miocene chalks were the youngest dredge haul material recovered at King's Trough Axis. Two rock cores postdate the dredge hauls. D9571 is mostly nannofossil-foraminiferal chalk with a top of (winnowed) foraminiferal sand and a base of zeolitic ash. D9574, from the opposite wall of King's Trough axis, a northern terrace on Antialtair Seamount, recovered largely nannofossil chalk of presumed middle Miocene age topped by a (winnowed) foraminiferal sand of Pleistocene age.

\section{Site 608}

Figure 12 outlines the reference section drilled at Site 608 for comparison with the age ranges of the Palmer Ridge and King's Trough Axis sampling. To date, Site 608 is probably the most completely sampled continuous Oligocene-to-Recent section drilled anywhere in the North Atlantic, and is certainly unique for the extent of its linked biostratigraphic and paleomagnetic record (Baldauf et al., this volume; Clement and Robinson, this volume). The lithologic record of events at Site 608 depicts vulcanicity, a major hiatus, and sediment instability, all of which we believe are related primarily to tectonic events at the trough axis.

Two holes were drilled-Hole 608 (continuously VLHPC- and XCB-cored to basement at $515.4 \mathrm{~m}$ subbottom); and Hole 608A (continuously VLHPC-cored to refusal at $146.4 \mathrm{~m}$ sub-bottom)-in order to provide overlap and an essentially complete sequence into the lower Pliocene. The paleontological age obtained for the basement at this site (NP17; Takayama and Sato, this volume) derives from nannofossils found on top and within the basement basalts; it is comparable with the age range of magnetic Anomaly 18 (41.29-43.6 Ma; Berggren, Kent, and Flynn, 1985a), upon which the drill site is situated.

Dolomite-bearing calcareous mudstone above basement and dolomitic marlstone through the middle Eocene give way upwards to upper Eocene marly nannofossil chalk containing graded volcaniclastic beds and volcanic ash layers. In a major hiatus at around $465 \mathrm{~m}$ sub-bottom, nannofossil Zones NP23 through NP20 are missing (Takayama and Sato, this volume); this hiatus represents about 9 m.y. Immediately above the hiatus is an interval of marly nannofossil chalk with flaser bedding and chalk conglomerate; the latter is interpreted as debris flow material, and together they indicate a period of slope sediment instability (Hill, this volume). The remaining upper Oligocene, the Miocene, and much of the Pliocene is a sequence of chalks to oozes that are marly (Oligocene and mid-Miocene) and become almost pure chalk upwards. Within the lower Miocene chalks at between 320 and $406 \mathrm{~m}$ sub-bottom, flaser bedding and microfaulting with slickensides were interpreted as representing a second period of sediment instability. This resulted in the formation of a second chalk conglomerate, which occurs at 369 to $375 \mathrm{~m}$ sub-bottom (Site 608 report, this volume). An input of disseminated volcanic ash also occurs in the middle Miocene chalks.

Glacial-interglacial cycles began at around $76 \mathrm{~m}$ subbottom in the lower Pliocene and continued upwards into the Holocene. A single turbidite bed was identified in 


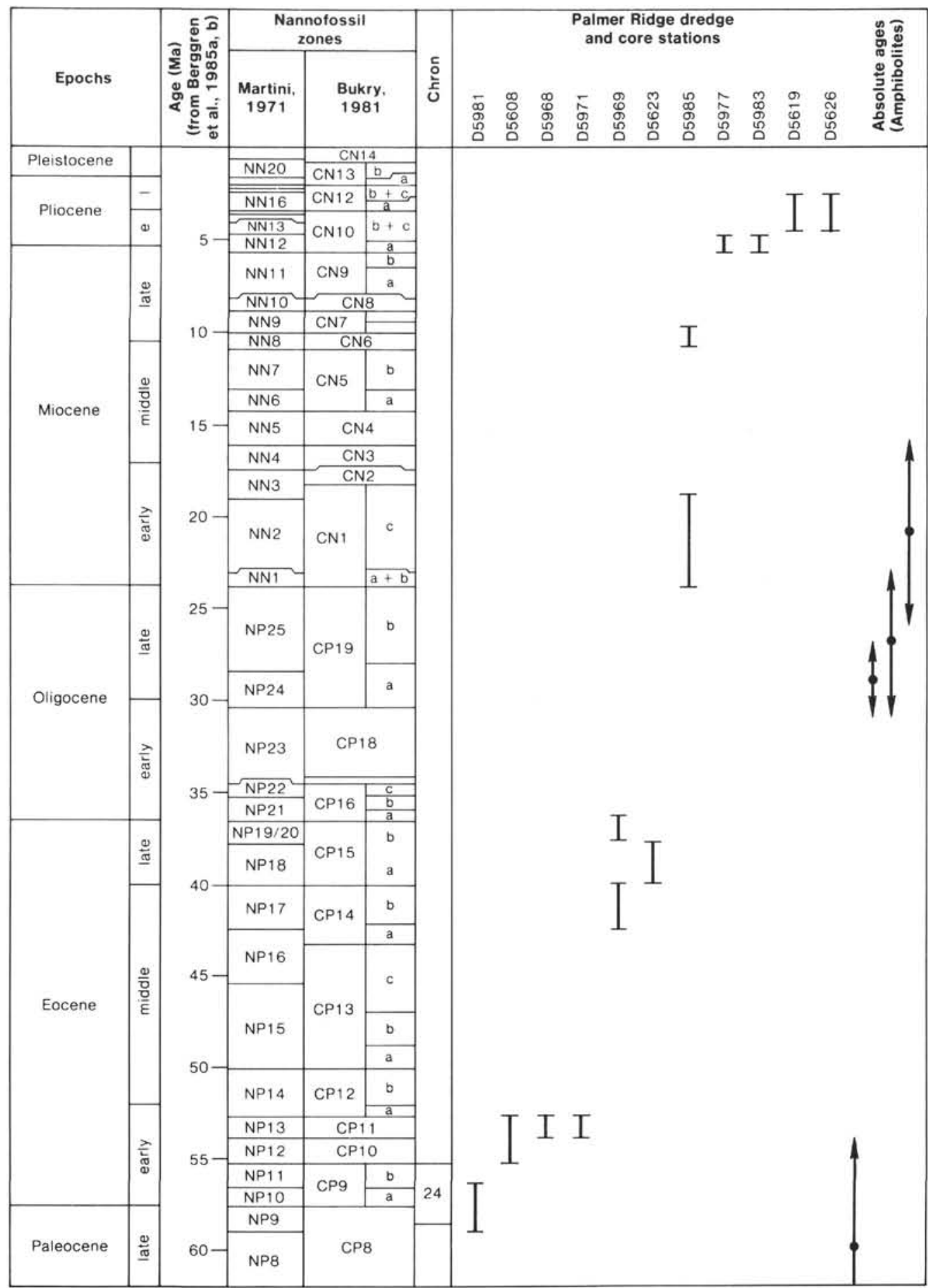

Figure 9. Palmer Ridge: age distributions of sediments recovered at dredge and core stations. The range of ages obtained by $\mathrm{K}-\mathrm{Ar}$ dating on amphibolites is also shown.

the upper Pliocene chalks, and this must also attest to some period of sediment instability on the south flank.

\section{THE MORPHOLOGY OF PALMER RIDGE AND KING'S TROUGH AND THE NATURE OF THE ROCK CORE AND DREDGE SAMPLES}

The terrains at Palmer Ridge and King's Trough (see Figs. 2 and 5 and back-pocket Figs. 3 and 4) are characterized by a series of terraces with intervening scarp slopes.
This topography, which is more pronounced at King's Trough Axis, has been attributed to step faulting, which occurred during rifting and the formation of the trough (Kidd et al., 1982). We believe the terraced morphology of Palmer Ridge has a similar origin.

The precision of the rock dredging and coring techniques used at King's Trough (Kidd et al., 1982) provided valuable information concerning the nature and ages of dredge samples recovered from the scarp and terrace terrains at these latitudes. Dredge sampling on the slopes 
Table 2. King's Trough: list of dredge and rock core stations used in this report.a

\begin{tabular}{|c|c|c|c|c|}
\hline Station & $\begin{array}{c}\text { Latitude N } \\
\text { to } \\
\text { Longitude W }\end{array}$ & $\begin{array}{c}\text { Latitude N } \\
\text { to } \\
\text { Longitude W }\end{array}$ & $\begin{array}{c}\text { Water } \\
\text { depth (m) }\end{array}$ & Comments \\
\hline \multicolumn{5}{|l|}{ Dredge } \\
\hline D7294 & $\begin{array}{l}44^{\circ} 02.30^{\prime} \\
21^{\circ} 56.83^{\prime}\end{array}$ & $\begin{array}{l}44^{\circ} 02.81^{\prime} \\
21^{\circ} 56.89^{\prime}\end{array}$ & $2370-1267$ & Weathered basalts and erratics \\
\hline D7296 & $\begin{array}{l}44^{\circ} 03.40^{\prime} \\
21^{\circ} 55.7^{\prime}\end{array}$ & $\begin{array}{l}44^{\circ} 03.42^{\prime} \\
21^{\circ} 55.37^{\prime}\end{array}$ & $2075-1109$ & Limestone and igneous erratics \\
\hline D7297 & $\begin{array}{l}44^{\circ} 05.25^{\prime} \\
21^{\circ} 55.77^{\prime}\end{array}$ & $\begin{array}{l}44^{\circ} 05.28^{\prime} \\
21^{\circ} 55.47^{\prime}\end{array}$ & $1750-934$ & Limestone and igneous erratics \\
\hline D9560 & $\begin{array}{l}43^{\circ} 50.67 \\
21^{\circ} 56.71^{\prime}\end{array}$ & $\begin{array}{l}43^{\circ} 49.69^{\prime} \\
21^{\circ} 56.88^{\prime}\end{array}$ & $4485-4530$ & $\begin{array}{l}\text { Chips of basalt and metamorphic } \\
\text { rock }\end{array}$ \\
\hline$\underline{\text { D9561 }}$ & $\begin{array}{l}43^{\circ} 50.18^{\prime} \\
21^{\circ} 50.15^{\prime}\end{array}$ & $\begin{array}{l}43^{\circ} 49.18^{\prime} \\
21^{\circ} 50.15^{\prime}\end{array}$ & $3791-3635$ & $\begin{array}{l}\text { Volcanic tuffs, ashes, hyaloclas- } \\
\text { tite, and nannfossil chalk }\end{array}$ \\
\hline D9562 & $\begin{array}{l}43^{\circ} 54.75^{\prime} \\
21^{\circ} 56.47\end{array}$ & $\begin{array}{l}53^{\circ} 53.90^{\prime} \\
21^{\circ} 55.22^{\prime}\end{array}$ & $3350-3187$ & $\begin{array}{l}\text { Trachyte, hyaloclastite, nannofos } \\
\text { sil chalk }\end{array}$ \\
\hline D9563 & $\begin{array}{l}43^{\circ} 53.66^{\prime} \\
21^{\circ} 57.57^{\prime}\end{array}$ & $\begin{array}{l}43^{\circ} 52.75^{\prime} \\
21^{\circ} 56.38^{\prime}\end{array}$ & $4117-3611$ & $\begin{array}{l}\text { Hyalociastite and nannofossil } \\
\text { chalk }\end{array}$ \\
\hline D9564 & $\begin{array}{l}43^{\circ} 49.09^{\prime} \\
21^{\circ} 54.08^{\prime}\end{array}$ & $\begin{array}{l}44^{\circ} 00.11 \\
21^{\circ} 54.08^{\prime}\end{array}$ & $2645-2446$ & $\begin{array}{l}\text { Basalts, hyaloclastite tuffs, ashes } \\
\text { nannofossil chalk; erratics }\end{array}$ \\
\hline D9565 & $\begin{array}{l}43^{\circ} 52.90^{\prime} \\
21^{\circ} 57.85^{\prime}\end{array}$ & $\begin{array}{l}43^{\circ} 51.57^{\prime} \\
21^{\circ} 56.41^{\prime}\end{array}$ & $4182-4080$ & Tuffs, ashes, and hyaloclastite \\
\hline D9566 & $\begin{array}{l}44^{\circ} 02.64^{\prime} \\
21^{\circ} 48.68^{\prime}\end{array}$ & $\begin{array}{l}44^{\circ} 02.92^{\prime} \\
21^{\circ} 48.56^{\prime}\end{array}$ & $1859-1856$ & Hyaloclastite \\
\hline D9572 & $\begin{array}{l}43^{\circ} 53.93^{\prime} \\
22^{\circ} 07.22^{\prime}\end{array}$ & $\begin{array}{l}43^{\circ} 54.04 \\
22^{\circ} 06.58^{\prime}\end{array}$ & $4544-4531$ & $\begin{array}{l}\text { Hyaloclastite, basalt, ash, } \\
\text { nannofossil chalk; erratics }\end{array}$ \\
\hline \multicolumn{5}{|l|}{ Core } \\
\hline D9567 & $\begin{array}{l}44^{\circ} 02.12^{\prime} \\
21^{\circ} 48.79^{\prime}\end{array}$ & & 1823 & $\begin{array}{l}\text { Core length recovered: } 75 \mathrm{~cm} \text {; } \\
\text { foraminiferal ooze; erratics }\end{array}$ \\
\hline$\underline{D 9568}$ & $\begin{array}{l}44^{\circ} 01.06 \\
21^{\circ} 47.45^{\prime}\end{array}$ & & 1751 & $\begin{array}{l}6 \mathrm{~cm} \text { of nannofossil chalk with } \\
\text { macrofossils }\end{array}$ \\
\hline D9570 & $\begin{array}{l}44^{\circ} 02.26^{\prime} \\
21^{\circ} 46.18^{\prime}\end{array}$ & & 2042 & $\begin{array}{l}\text { No core; hyaloclastite fragments } \\
\text { in core catcher }\end{array}$ \\
\hline D9571 & $\begin{array}{l}44^{\circ} 02.80^{\prime} \\
21^{\circ} 47.03^{\prime}\end{array}$ & & 2009 & $\begin{array}{l}\text { Core length recovered: } 125 \mathrm{~cm} \text {; } \\
\text { foraminiferal ooze and } \\
\text { nannofossil chalk overlie } \\
\text { zeolitic ash }\end{array}$ \\
\hline D9573 & $\begin{array}{l}43^{\circ} 34.3^{\prime} \\
22^{\circ} 23.4^{\prime}\end{array}$ & & 973 & $\begin{array}{l}\text { No core; chips of basalt and } \\
\text { bryozoans }\end{array}$ \\
\hline D9574 & $\begin{array}{l}43^{\circ} 33.5^{\prime} \\
22^{\circ} 23.9^{\circ}\end{array}$ & & 1141 & $\begin{array}{l}\text { Core length recovered: } 38 \mathrm{~cm} \text {; } \\
\text { foraminiferal nannofossil } \\
\text { chalk and volcanic rock } \\
\text { fragments }\end{array}$ \\
\hline
\end{tabular}

Note: Ages of the samples can be found in Figure II. Stations underlined recovered rocks with age ranges not sampled at Site 608.

Core Stations 9573 and 9574 were recovered from Antialtair Seamount and do not appear in Figure 8.

of the trough axis, and subsequent sorting out of glacial erratic material (Huggett and Kidd, 1984/85), has shown that:

- The oldest in situ rocks (volcanics, intrusives, or chalks) are recovered from, and therefore must crop out on, the slopes of the fault scarps.

- Rock screes are generated at the base of the slopes as a result of erosion at the slope outcrops.

- The youngest deposits, the ice-rafted glacial erratics and Pleistocene to Recent pelagic ooze, occur on the broad terraces.

These conclusions are supported by direct observations made previously from camera runs on the flanks of Palmer Ridge and King's Trough (Laughton et al., 1971).

Results of rock coring on the fault scarp slopes indicate that these features were never significant sites of sediment accumulation. Cores from these slopes show that the fault-exposed older Tertiary sediments either crop out or are overlain by a thin veneer of Pleistocene or Quaternary deposits.

Dredging is obviously a poor substitute for continuous coring through drilling, and we cannot be certain that a dredge haul has sampled all the lithologies or biozones that may crop out on the fault scarp slopes. We do, however, believe that the stratigraphic sequences that are derived by interpreting the age ranges of dredge samples recovered at Palmer Ridge and King's Trough Axis

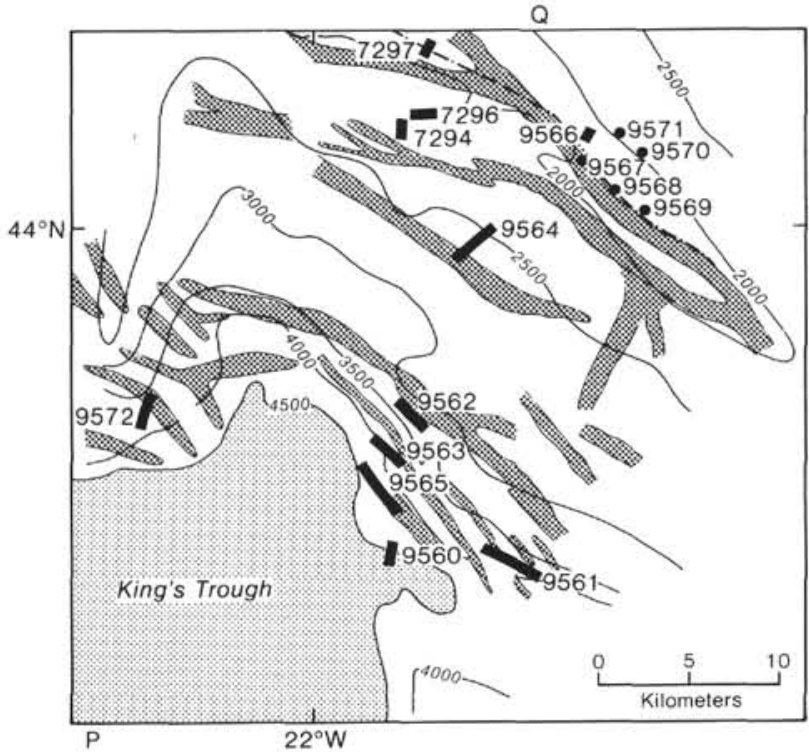

Figure 10. King's Trough Axis detailed dredge and rock core sampling area. Bathymetry in corrected meters: ship's traverses at dredge stations shown as solid heavy lines with station numbers, rock core stations as large dots with station numbers. The crest of the north flanking ridge is marked by the dashed and dotted line: heavy stippling illustrates the areas of outcrop detected by GLORIA sonographs; light stippling defines the floor of King's Trough (depths greater than $4500 \mathrm{~m}$ ). P and Q allow location of part of the seismic reflection profile in Figure 2.

are meaningful and not simply a product of sampling technique. This conclusion is based on the following:

- the similarity in the results obtained by sampling sequences that are repeated at different elevations by step faulting;

- the coincidence between the stratigraphic records of the two detailed dredge sampling areas that share a similar tectonic setting.

The age of samples recovered from Palmer Ridge and the King's Trough Axis appear to provide adequate, though probably incomplete, records of the stratigraphy at these locations. Continuous coring at Site 608 has provided a section to combine with the post-43-Ma parts of these sequences.

\section{TOWARDS A COMPOSITE STRATIGRAPHIC SEQUENCE}

In Tables 1 and 2 we indicate the dredge hauls and rock cores that contained samples of an age range that was not recovered at Site 608. These particular dredges and cores also frequently contained rocks of ages that were drilled.

Samples that cover the age range of the major upper Eocene through lower Oligocene hiatus at Site 608 were recovered at both King's Trough Axis and Palmer Ridge (Figs. 9 and 11). In both cases, uppermost Eocene material of nannofossil Zones NP18 through NP20 was recovered. This would serve to constrain a regional hiatus, based on biostratigraphic ages, to a maximum time span of around 6 m.y. (Fig. 13).

At Palmer Ridge a 14.2-m.y. gap in the age distribution pattern separates samples from the upper Eocene and lower Miocene (nannofossil Zone NP19/20 from 


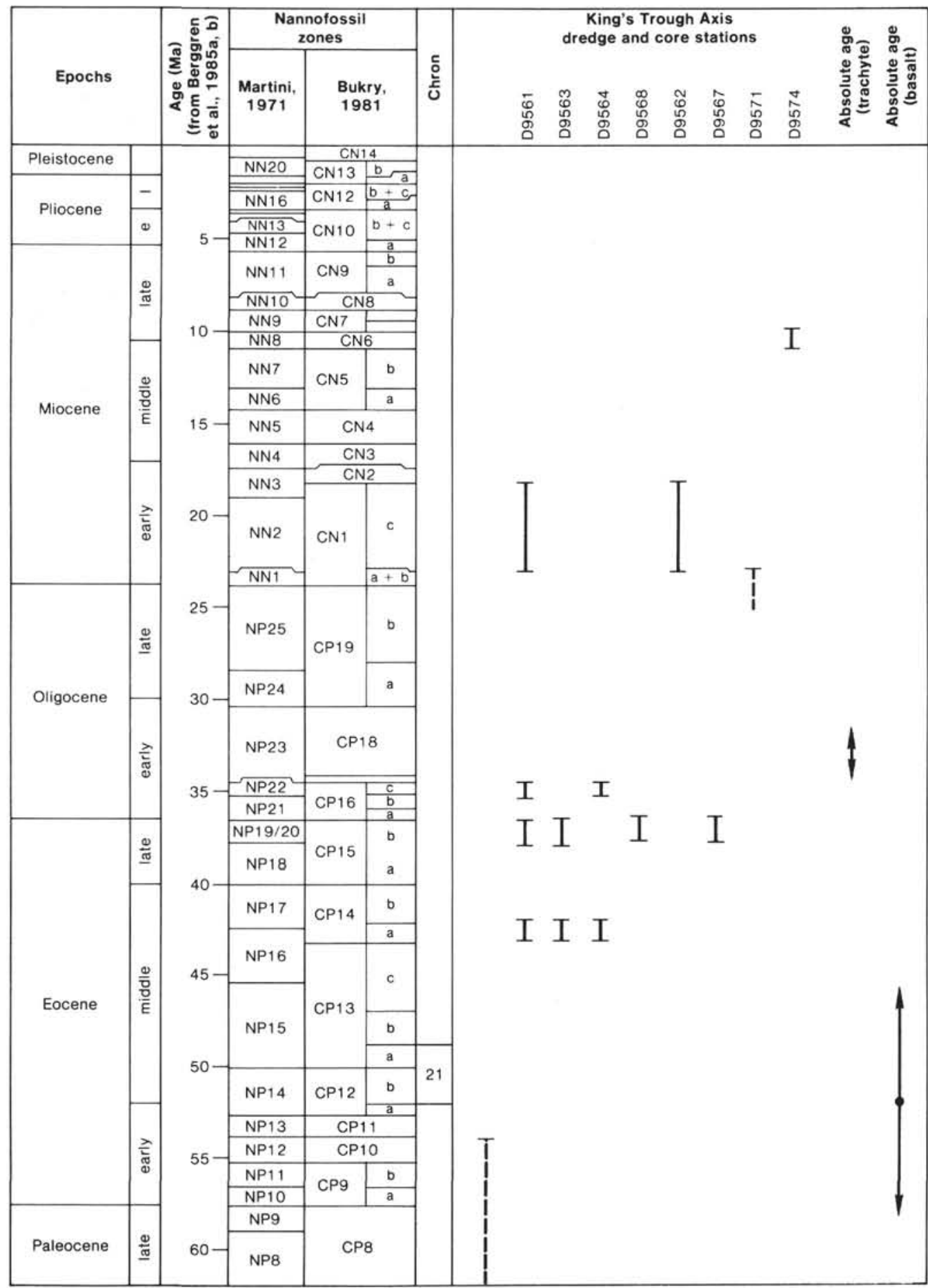

Figure 11. King's Trough: age distribution pattern of sediments recovered at dredge and core stations. The range of ages obtained by K-Ar dating on basalts and trachytes is also shown.

Zone NN1). Similarly, a 13-m.y. break in the age distribution of chalks recovered at the King's Trough Axis separates the upper Eocene/lower Oligocene and lower Miocene nannofossil chalks (Zone NP21 from Zone NN1). $\mathrm{K}$-Ar dating of trachyte intrusives recovered at the same location gave ages in the range 32 to $34 \mathrm{Ma}$ with a mean age of 32.2 Ma (Kidd et al., 1982). As noted previously, these intrusives are associated with undated, shallow-water to subaerial, trachytic tuffs.

Because of the older basement ages in dredging and rock coring areas, samples were recovered that predate the oldest lithologies at Site 608 . These dredge samples were ashy and zeolitic nannofossil chalks that are characterized by strikingly different nannofossil assemblages. 


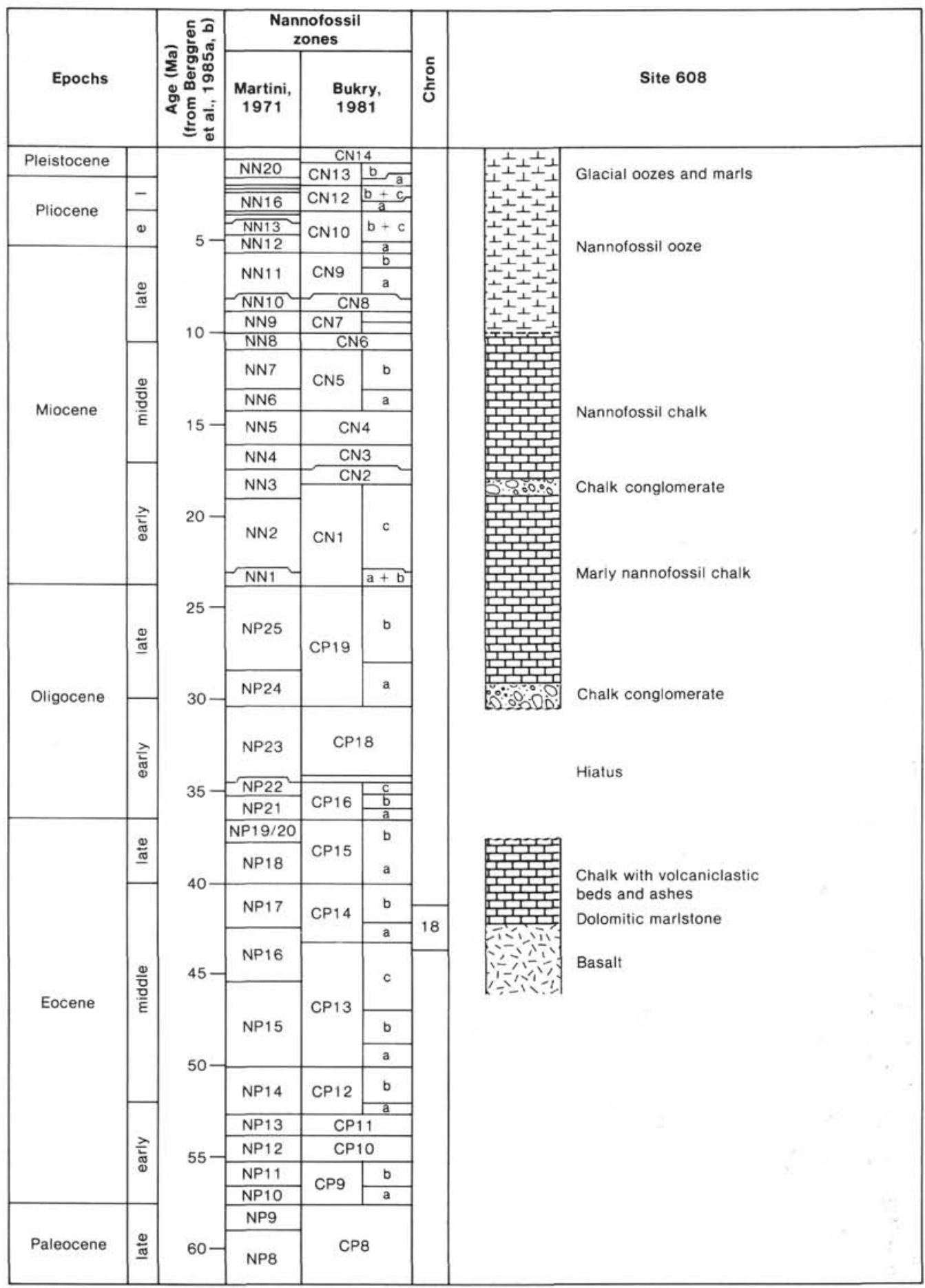

Figure 12. Detail of the age ranges of rocks and sediments recovered by continuous coring at Site 608 . Age of oceanic basement derived from its location on magnetic Anomaly 18. Note that not all of the nannofossil zones listed under "Martini, 1971" were recognized in the lithologies at Site 608, and some correlations with the geomagnetic polarity time scale differ from those given in Baldauf et al. (this volume).

At Palmer Ridge, high species diversity is characteristic of assemblages in samples from stations D5981 and D5608 and core D5971. They contain abundant discoasters and are typical of deep, open marine environments. At King's Trough the oldest sediment recovered in dredge D9572 contains a low-diversity, restricted assemblage of small coccoliths and discoliths. The majority of speci- mens are heavily coated by calcite overgrowths that makes their taxonomic identification difficult. This anomalous nannofossil assemblage may be evidence of shallow-water deposition around an elevated mid-ocean ridge crest at approximately $54 \mathrm{Ma}$.

Samples from both the King's Trough Axis and Palmer Ridge contain breaks in their age distribution pat- 

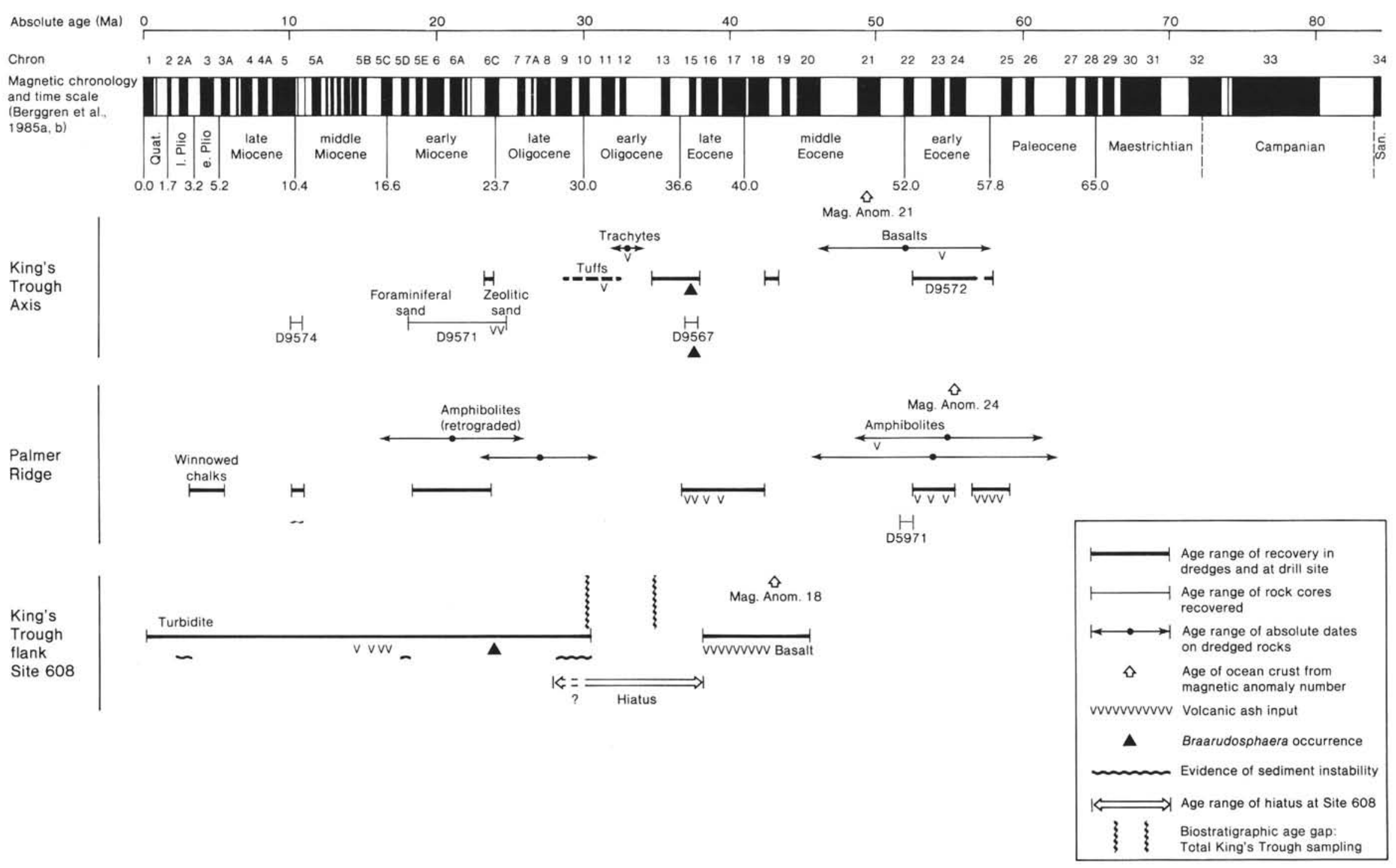

Figure 13. Comparison of the drilled stratigraphy at Site 608 with the age ranges of samples recovered at King's Trough and Palmer Ridge by dredging and rock coring. The age gap remaining for total sample recovery within the complex is indicated against Site 608 . 
terns that may or may not be significant. The breaks are approximately synchronous and could suggest the presence of a middle Eocene sedimentary hiatus.

\section{DATING THE REGIONAL REFLECTOR}

One of the objectives of drilling at Site 608 was to provide an age for the regional seismic reflector that is recognized on both north and south flanks of the King's Trough complex and that had not previously been dated with any certainty by dredging. Studies in the south flank province (Kidd et al., 1983) had traced the reflector well to the south (to within $200 \mathrm{n}$. mi. of the Azores) and eastwards to the Azores-Biscay Rise (Fig. 6). This tracing had shown that, in fact, two regional reflectors characterize much of the eastern part of this area. The reflector near King's Trough is the upper of the two, but both reflectors are well displayed on seismic records passing up to the flanks of the Azores-Biscay Rise (Whitmarsh et al., 1982). The upper reflector lies between 0.2 and $0.4 \mathrm{~s}$ sub-bottom over most of the area whereas the lower is between 0.4 and $0.6 \mathrm{~s}$ (two-way traveltime). A uniform separation of about $0.2 \mathrm{~s}$ appears characteristic, and basement highs frequently truncate the reflectors.

The seismic section drilled at Site 608 is described in detail in the Site 608 report (this volume). The correlation of acoustic and lithologic stratigraphy (Fig. 14) indicates that the top of acoustic Unit E, at $0.37 \mathrm{~s}$, is the traceable upper reflector. Lithologically, the reflector represents the top of sedimentary Unit VI (the chalks with volcaniclastic beds and disseminated ashes) and is coincident with the major hiatus and overlying chalk conglomerate. Its age is therefore late Eocene-early Oligocene.

Structurally, the sequences overlying the reflector show clear angular unconformity with the underlying volcanic glass-rich chalks. The reflector at this location and northwards to the trough axis is obviously tectonically produced. Further south, where angular unconformity seems to disappear, the reflector may simply represent the top of a volcanic glass-rich chalk sequence similar to Unit VI, and a hiatus may or may not be present.

Both the upper and lower regional reflectors probably relate to tectonic-volcanic events, first at the AzoresBiscay Rise (Whitmarsh et al., 1982) and later at King's Trough. On the other hand, it may be argued (Miller and Tucholke, 1983) that the Site 608 reflector (the regional upper reflector) could indeed be represented as a hiatus regionally because it is linked to an Eocene-Oligocene change in North Atlantic bottom-water circulation. In addition, we note that the pattern of dredgehaul ages tentatively suggests that some of the middle Eocene may also be missing at King's Trough Axis and Palmer Ridge.

Locally around the drill site, the top of acoustic Unit C, at around $0.12 \mathrm{~s}$ sub-bottom (Fig. 14), has an unconformable relationship with acoustic Units A and B above (see fig. 5A, Site 608 report, this volume). This we think reflects tectonic instability that initiated the slope instability displayed by the chalks of Unit C (Hill, this vol- ume). This angular unconformity is not seen on a regional scale.

\section{TESTING THE PREVIOUS MODELS}

Kidd et al. (1982) used their sampling data to make a choice between two models of formation for the King's Trough complex that had been put forward by Searle and Whitmarsh (1978) based on geophysical data. Here we can use refined dating of the samples and the Site 608 results to examine their models and to look for other possibilities.

Searle and Whitmarsh (1978) used:

(1) seismic reflection and gravity results to show that the King's Trough complex is characterized by thicker than average crust (Louden [1983] independently came to the same conclusion by determining elastic plate thickness from gravity models);

(2) regional bathymetry to emphasize the general shallowness of the area and its counterpart "bulge" on the west side of the MAR: this they interpreted as evidence of unusually voluminous ridge crest volcanism (a "hot-spot" center);

(3) magnetic anomaly distributions to demonstrate minimal displacement across the complex between Anomalies 24 (56 Ma) and 6a (about $21 \mathrm{Ma}$ ), and to discount the possibility that King's Trough might be a fracture zone (Miles and Kidd [this volume] agree that the Trough axis is not a transform, but have identified a number of small transform faults in the south flank);

(4) backtracking along an average ocean age-depth subsidence curve (Parsons and Sclater, 1971) to show that flanking ridges within the complex could have been subaerial at some time in their history.

Both of the models that Searle and Whitmarsh (1978) proposed had the King's Trough ridges originate at a spreading center hot spot and the basins and deeps form by extension, possibly with some shear (Fig. 15). In one, Model a, rifting occurred in an ultraslow spreading arm of a triple junction associated with the hot spot. In the other, Model b, rifting happened after the development of a hot-spot ridge, either as an intraplate tectonic event or as a short-lived plate boundary.

Kidd et al. (1982) made paleoenvironmental interpretations for each of the rock types that they recovered and then tried to construct a tectonic history based on the ages. Here we will repeat this process in order to reconsider the models.

At all three major sampling locations, typical midocean ridge tholeiitic basalts are the oldest rocks present, and they are associated with open-ocean nannofossil chalks (Figure 13). Basalt and sediment ages concur with magnetic anomaly ages, confirming that each location evolved at a spreading center. Hyaloclastite, a typical associate of pillow basalts, is present at King's Trough Axis. Possible age-equivalent amphibolites, gabbros, and serpentinites at Palmer Ridge suggest a subsequent exposure of deeper layers of ocean crustal structure by some tectonic event (Cann and Funnell, 1967). The Eocene chalks as a whole are generally zeolitic or volcanic ash- 


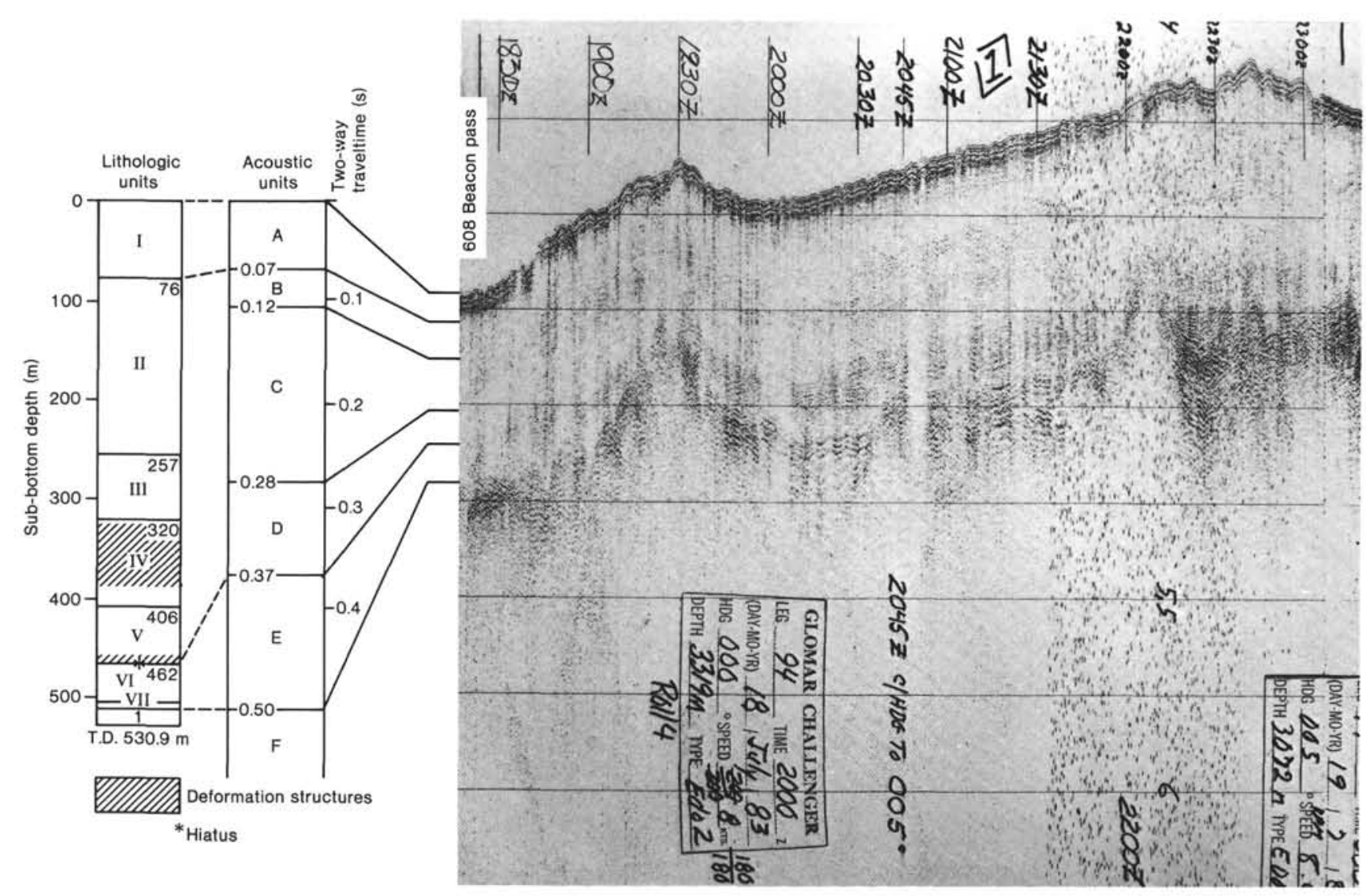

Figure 14. Seismic stratigraphy and comparison with lithologic units at Site 608; for explanation see text as well as the Site 608 report (this volume).

rich, showing that explosive volcanicity, indicating relatively shallow water at the spreading ridge (McBirney, 1963), influenced deposition for at least 5 m.y. after crustal formation at each site. Formation at a hot spot, as suggested by Searle and Whitmarsh, would seem an explanation for this continued volcanicity, although there is no evidence anywhere of extremely shallow-water conditions until the latest Eocene.

The middle and upper Eocene sediments (post-43 Ma) at all three locations are nannofossil chalks, some zeolitic, with volcanic ashes. Volcanoclastic turbidites also occur at Site 608. At the King's Trough Axis, upper Eocene chalks that contain Braarudosphaera bigelowi are found in dredge hauls containing volcanic tuffs. Takayama (1972) has shown that $B$. bigelowi commonly occurs in water less than $100 \mathrm{~m}$ deep and is rare below depths of $150 \mathrm{~m}$ to $200 \mathrm{~m}$. Ramsay $(1971,1972)$ found this species in sediments that accumulated about the Bermuda Pedestal, which formed a basement high in the Paleogene North Atlantic. At King's Trough Axis, the shallow-water species could be in situ or could have been derived by the downslope reworking of sediment from a nearby elevated area about the trough axis.

At Site 608, the major hiatus eliminates the record of deposition and paleoenvironments during the late Eocene-early Oligocene (Zones NP23 through NP20 are missing; Takayama and Sato, this volume). Nannofossil chalks and volcanic ashes of this age were recovered at
King's Trough Axis, but no age-equivalent recovery was recorded at Palmer Ridge. Trachytes and tuffs were also recovered at King's Trough Axis and these are perhaps the most important rocks with which to interpret the tectonic history.

Kidd et al. (1982) described a gradation within the assemblage of trachytic rocks from fresh unmetamorphosed trachytes to altered "greenschist facies" trachytes. Despite this, $\mathrm{K}-\mathrm{Ar}$ ages of both end members gave a range of only 32 to $34 \mathrm{Ma}$. The trachyte intrusives were recovered in hauls from a range of water depths on inwardfacing fault scarps and it appears likely that they were intruded at around $32 \mathrm{Ma}$, but that later step-faulting exposed deeper structural levels in these intrusions. Stebins and Thompson (1978) emphasized that the rocks they gathered from the flanks of Antialtair Seamount probably provided a sampling of varying levels of its former magma chamber. Trace element chemistry and mineralogy showed that the assemblage was alkaline in nature and clearly resulted from intraplate rather than spreading-center volcanism.

The volcanic tuffs found at King's Trough Axis by both Kidd et al. (1982) and Stebbins and Thompson (1978) are also alkaline, and they provide evidence that in the early Oligocene, parts of the axial complex were near sea level. Large clasts of the trachytes appear within the unwelded tuffs, arguing for a local derivation from a distance of no more than a few kilometers and showing that 

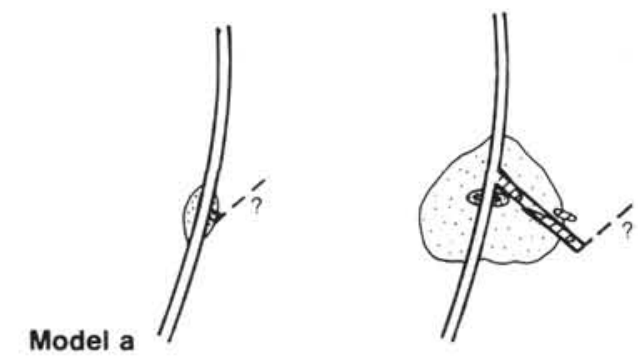

Anomaly no: 24

Age $(\mathrm{Ma})$ :
19

44

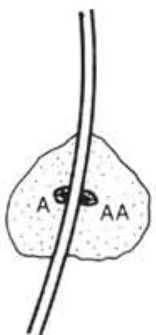

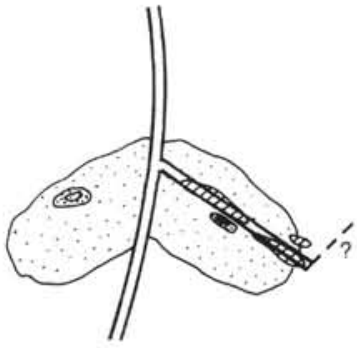

$6 a$

21

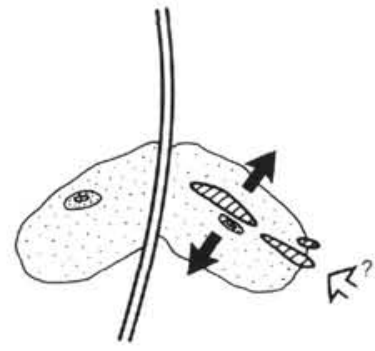

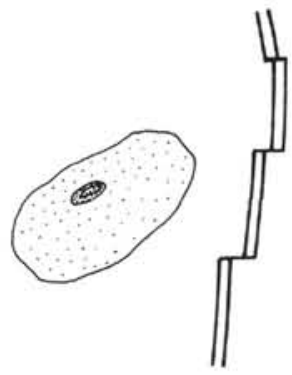

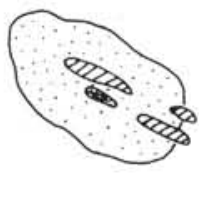

Present

0

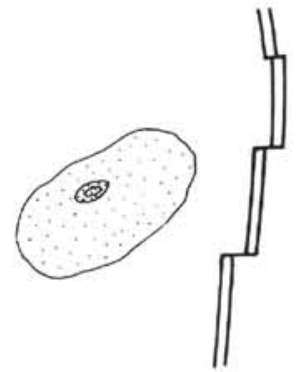

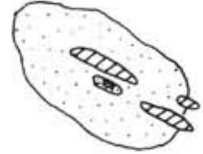

Figure 15. Models for the formation of the King's Trough complex proposed by Searle and Whitmarsh (1978); see text for explanation of a and b. $(\mathrm{A}=$ Altair Seamount; $\mathrm{AA}=$ Antialtair Seamount. $)$

the trachytes were emplaced before or at the same time as deposition of these tuffs. Traces of foraminifers, diatoms, and rounded glauconite grains suggest a shallowwater origin. Our detection of Braarudosphaera chalks that predate the tuffs lends further support to this notion.

Contrary to ideas of a triple-junction spreading arm (Model a), it now seems clear that an intraplate volcanictectonic event both emplaced the trachyte intrusives and caused the angular unconformity in the seismic sequences of the King's Trough flanks. How much uplift occurred is uncertain. Previously, Kidd et al. (1982) argued that the hot-spot ridge may have subsided, in parallel with normal ocean crust to the north and south, such that the King's Trough Axis location would have required an uplift of up to $2 \mathrm{~km}$ to take it near sea level in the Oligocene. Upper Eocene volcaniclastic turbidites recovered at Site 608 and the coeval Braarudosphaera chalks at King's Trough Axis show that some relative relief already existed between the flank and the axis in the late Eocene. The fact that tuff fragments are contained in the turbidites suggests that the ridge had not subsided greatly. It seems possible that the ridge was simply a line of volcanic seamounts similar to Antialtair, on which subsidence rates were reduced by continued volcanic activity. Intraplate intrusion of the trachytes probably did cause uplift, thus the angular unconformity, but this need not have been on the scale previously envisaged.

Above the major hiatus at Site 608, lower Oligocene chalk conglomerates and flaser chalks of Zone NP24 provide evidence of debris flow processes and other slope instability (Hill, this volume). The cause was probably continued tectonism associated with the intraplate volcanism in the axial region. This tectonism must have died down for the remaining Oligocene and earliest Miocene (28-23 Ma). No evidence of slope instability or microfaulting during this interval is present at Site 608, although traces of presumably displaced Braarudosphaera occur.

The drilled sequence suggests that a second period of tectonism took place in the early Miocene. Nannofossil chalks with microfaults and sediment flow structures make up lithologic Unit IV (see Site 608 report, this volume). Flaser chalks and microfaulting become most abundant in Core 608-40, which contains another chalk conglomerate. This might suggest that the tectonism was centered on nannofossil Zone NN3, the zonal age given to Core 40 (Takayama and Sato, this volume). This zonal assignment places the age of maximum tectonic activity between 18 and $22 \mathrm{Ma}$ (Baldauf et al., this volume).

At King's Trough and Palmer Ridge, the coincidence between the age distibution patterns of dredge and rock core samples recovered from the sequence above the major hiatus is striking. If significant, these patterns indicate an interval of continuous sedimentation between nannofossil Zones NN1 and NN2 (23.6-19 Ma) followed by a series of breaks in the age distribution of the samples. We suggest that the breaks are the result of the rifting and downfaulting of the King's Trough basins and Peake and Freen deeps and that, in the drill site outside the 
main tectonic zone, the rifting is expressed by slope instability. We infer that uplift of King's Trough's axis has resulted in both erosion (the hiatus) and slope instability on the south flank, whereas rifting and downfaulting of the axis is represented by slope instability at Site 608 .

We imply above that both King's Trough and Peake and Freen deeps were formed by downfaulting during a rifting period that took place at around $18 \mathrm{Ma}$. A time scale revision makes this event seem later than in Searle and Whitmarsh's Model b, but it would still be centered on Anomaly 6a (Fig. 15). If the axis was near sea level prior to this time, a total downdrop of around $3 \mathrm{~km}$ must have occurred on the internal step faults.

Cann and Funnell (1967) and Ramsay (1970) suggested that Palmer Ridge formed by uplift and serpentinite intrusion at about $21 \mathrm{Ma}$. This was believed coincident, with retrograde metamorphism of some of the amphibolite assemblage that they had collected. Here we suggest that the Ridge was simply isolated by extension and subsidence of the deeps on either side. Their observation that "winnowed" chalks characterized deposition on the Ridge after "uplift" is equally served by this hypothesis. The age range given for the retrograde metamorphism (Fig. 13) shows that it could have occurred in concert with the second phase of tectonism detected at Site 608 but that this event was unrelated in time to the activity that caused the major hiatus.

Further evidence of major rifting of King's Trough during the mid-early Miocene comes from Louden (1983) who showed that the topography of the complex is regionally isostatically compensated on lithosphere older than $20 \mathrm{Ma}$. He also concluded that this rifting was an intraplate event because it occurred away from the midocean ridge, and there was no structural evidence in the crustal behavior of formation as a compressional boundary.

\section{REGIONAL IMPLICATIONS}

Our discussion above strongly favors Searle and Whitmarsh's Model b with only minor refinements for the timing of the major events. The latter are largely caused by revisions to time scales. All the evidence points to an early Miocene intraplate rifting event causing the basins and deeps in the complex. Some of the relief of the complex's ridges may have developed earlier, when uplift occurred in the early Oligocene and tilted the flanks. By examination of this timing in relation to other tectonic developments in the region, we gain some insight into likely causes of the events.

Grimaud et al. (1982 and 1983) followed LePichon and Sibuet (1971) in considering King's Trough as a former plate boundary or transform fault. This does not now seem to be the case, but their linking of events at King's Trough with the timing of the Pyrenean orogeny is interesting and worthy of consideration. The main phase of orogenesis in the Pyrenees ended in the uppermost Eocene ( $\sim 37 \mathrm{Ma}$ ?) and is expressed as a major angular unconformity in regional sequences (Mattauer and Henry, 1974). This is coincident with the hiatus and angular unconformity at King's Trough. A third phase of Pyrenean folding occurred during the late Oligocene to early
Miocene, but is not reflected by compression at King's Trough, which went through extension at this time.

Whitmarsh et al. (1982) considered the Azores-Biscay Rise east of the King's Trough complex (Fig. 1) to be a hot-spot ridge that was generated with an ENE-WSW trend between 76 and $56 \mathrm{Ma}$. They speculated that hotspot activity then moved northwards on the Mid-Atlantic Ridge and subsequently formed the "King's Trough High." Clearly, the timing of the move at Anomaly 24 fits well with the ages of basalts and amphibolites at Palmer Ridge. The deeper regional seismic reflector present southeastwards from King's Trough may represent the top of volcanic glass-rich sediments contributed by the Azores-Biscay Rise during its active phase.

We do not speculate here on the causes of the extension and rifting of the King's Trough complex. Plate kinematic models based on magnetic-anomaly identifications are currently being refined for the Northeast Atlantic (e.g., Srivastava and Tapscott, in press). We consider it sufficient at this stage to present the evidence of the drill, dredge haul, and rock core as a test of these regional tectonic assessments.

\section{CONCLUSIONS}

The availability of a continuously cored record for drill Site 608 has provided a framework within which the results of past dredge and rock core sampling in the King's Trough complex can be correlated, compared, and interpreted. The dredge hauls of the King's Trough Axis and Palmer Ridge contain lithologicai and biostratigraphical units that are absent at Site 608 .

The results of the above exercise confirm previous models for the formation of the King's Trough complex (Kidd et al., 1982; Searle and Whitmarsh, 1978). The complex was most probably generated by a combination of: (1) initial spreading from an elevated part of the midocean ridge; (2) an uplift that was associated with igneous intrusion and volcanicity at approximately $32 \mathrm{Ma}$; and (3) a period of extensional subsidence and rifting between 16 and $20 \mathrm{Ma}$. The phase of uplift was associated with slope instability, the generation of debris flows, and the formation of a hiatus in the sedimentary sequences of both Palmer Ridge and Site 608 on the south flank of the King's Trough feature. Fault movements on the flanks of Palmer Ridge and inner flanks of King's Trough, both during uplift and the extensional phase, prohibited continuous sediment accumulation there and resulted in sequences that are characterized by conspicuous breaks. At Site 608 the occurrence of chalk conglomerates dated at between 18 and 22 Ma defines a disrupted interval in an otherwise continuous sequence of undisturbed Oligocene to Recent sediments. This disturbance seems to correlate with sedimentary breaks at the axis and at Palmer Ridge. It was probably also caused by slope instability that was associated with the extensional rifting process at the trough axis.

Both of the prime tectonic events at King's Trough were intraplate in nature, contrary to ideas that the complex might represent a defunct plate boundary. How much uplift occurred during the intraplate volcanism at about $32 \mathrm{Ma}$ is uncertain. The hiatus at Site 608 is clearly tec- 
tonic in nature, but towards the south the seismic reflector that was drilled may reflect either the explosive volcanicity at the trough axis or extension of a regional hiatus due to bottom current erosion. Extension and rifting of the complex occurred later and independently of compressive events east of the Azores-Biscay Rise or through to the Pyrenees, and there is no evidence to suggest that the complex represents a former transform. Palmer Ridge became isolated during the extension phase as subsidence of Peake and Freen deeps on either side exposed deeper crustal levels.

\section{ACKNOWLEDGMENTS}

The shipboard scientific team aboard Glomar Challenger for DSDP Leg 94 is acknowledged for their interest and support in a tectonic project inserted within the paleoenvironmental objectives of the leg. RBK wishes to thank them, and colleagues at IOS Wormley, for sharing their enthusiasm and ideas. A.S. Laughton is acknowledged for permission to use a modified version of his Palmer Ridge illustration (Fig. 5). Peter Hunter (IOS) constructed the revised bathymetric map for back-pocket Figure 4 and, along with Colin Jacobs and Amanda Bates, is thanked for drafting the figures. Typing was done by Anne Graham at ODP/TAMU. Some survey work reported here was carried out under contract to the U.K. Department of the Environment. This chapter bears ODP designation: ODP/P-86/014.

\section{REFERENCES}

Berggren, W. A., Kent, D., and Flynn, J. J., 1985a. Paleogene geochronology and chronobiostratigraphy. In Snelling, N. J. (Ed.), The Chronology of the Geological Record. Geol. Soc. London Mem., 10:141-186.

Berggren, W. A., Kent, D., and Van Couvering, J. A., 1985b. Neogene geochronology and chronobiostratigraphy. In Snelling, N. J. (Ed.), The Chronology of the Geological Record. Geol. Soc. London Mem., 10:211-260.

Bukry, D., 1973. Low latitude coccolith biostratigraphical zonation. In Edgar, N. T., Saunders, J. B., et al., Init. Repts. DSDP, 15: Washington (U.S. Govt. Printing Office), 685-703.

, 1975. Coccolith and silicogflagellate stratigraphy, Northwestern Pacific Ocean. In Larson, R. L., Moberly, R., et al., Init. Repts. DSDP, 32: Washington (U.S. Govt. Printing Office), 667-701. , 1981. Cenozoic coccoliths from the Deep Sea Drilling Project. Soc. Econ. Paleontol. Mineral. Spec. Pub., 32:335-353.

Cann, J. R., 1971. Petrology of basement rocks from Palmer Ridge, N.E. Atlantic. Phil. Trans. R. Soc. (London) Ser. A, 268:605-664.

Cann, J. R, and Funnell, B. M., 1967. Palmer Ridge: a section through the upper part of the ocean crust? Nature, 213:661-664.

Davies, T. A., and Jones, E. J. W., 1971. Sedimentation in the area of Peake and Freen deeps (Mid-Atlantic Ridge). Deep-Sea Res., 18: 619-630.

Grimaud, S., Boillot, G., Colette, B. J., Mauffret, A., Miles, P. R., and Roberts, D. G., 1982. Western extension of the Iberian-European plate boundary during the early Cenozoic (Pyrenean) convergence: a new model. Mar. Geol., 45:63-77.

1983. Western extension of the Iberian-European plate boundary during the early Cenozoic (Pyrenean) convergence: a new model-reply. Mar. Geol., 54:238-239.

Haq, B. U., 1983. Jurassic to Recent nannofossil biochronology: an update. In Haq, B. U. (Ed.), Benchmark Papers in Geology (Vol. 78): Stroudsberg, PA (Hutchinson Ross Publishing Co.), 358-378.

Huggett, Q. J., and Kidd, R. B., 1984/85. The identification of icerafted and other exotic material in deep sea dredge hauls. Geomar. Lett., 3:23-29.

Kidd, R. B., Searle, R. C., Ramsay, A. T. S., Pritchard, H., and Mitchell, J., 1982. The geology and formation of King's Trough, Northeast Atlantic Ocean. Mar. Geol., 48:1-30.

Kidd, R. B., Searle, R. D., Weaver, P. P. E., Jacobs, C. L., Huggett, Q. J., Noel, M. J., and Schultheiss, P. J., 1983. King's Trough
Flank: geological and geophysical investigations of its suitability for high-level radioactive waste disposal. Institute of Oceanographic Sciences Report 166, Wormley, Surrey, U.K.

Kristofersson, Y., 1978. Sea-floor spreading and early opening of the North Atlantic. Earth Planet Sci. Lett., 38:273-290.

Laughton, A. S., 1965. Bathymetry of the Northeastern Atlantic Ocean and recent geophysical studies. In Whittard, W. F., and Bradshan, R. (Eds.), Submarine Geology and Geophysics: London (Butterworth), pp. 175-176.

1982. The first decade of GLORIA. J. Geophys. Res., 86: $11511-11534$

Laughton, A. S., et al., 1971. RSS Discovery Cruise 33, NIO Cruise Report 33. National Institute of Oceanography, Wormley, Surrey.

Le Pichon, X., and Sibuet, J. C., 1971. Western extension of the boundary between the European and Iberian plates during the Pyrenean Orogeny. Earth Planet. Sci. Lett., 12:83-88.

Louden, K. E., 1983. A note on the isostatic compensation and origin of King's Trough. Geophys. J. R. Astron. Soc., 75:555-563.

McBirney, A. R., 1963. Factors governing the nature of submarine volcanism. Bull. Volcanol., 26:455-469.

Martini, E., 1971. Standard Tertiary and Quaternary calcareous nannoplankton zonation. In Farinacci, A. (Ed.), Second Plankt. Conf. Proc. Roma, 1970: Rome (Tecnoscienza), pp. 739-785.

Mattauer, M., and Henry, J., 1974. Pyrenees. In Spencer, A. M. (Ed.), Mesozoic-Cenozoic Organic Belts: Data for Orogenic Studies. Spec. Publ. Geol. Soc. London, 4:3-22.

Matthews, D. H., Laughton, A. S., Pugh, D. T., Jones, E. J. W., Sunderland, J., Takin, M., and Bacon, M., 1969. Crustal structure and origin of Peake and Freen Deeps, N.E. Atlantic. Geophys. J.R. Astron. Soc., 18:517-542.

Okada, H., and Bukry, D., 1980. Supplementary modification and introduction of code numbers to the low-latitude biostratigraphic zonation (Bukry, 1973, 1975). Mar. Micropaleontol., 5:321-325.

Parsons, B., and Sclater, J. G., 1971. An analysis of the variation of ocean floor bathymetry and heat flow with age. J. Geophys. Res., $82: 803-827$.

Ramsay, A. T. S., 1970. The pre-Pleistocene stratigraphy and palaeontology of the Palmer Ridge area, N.E. Atlantic. Mar. Geol., 9: 261-285.

1971. The investigation of Lower Tertiary sediments from the North Atlantic. In Farinacci, A. (Ed.), Second Plankt. Conf. Proc. Roma, 1970: Rome (Technoscienza), pp. 1039-1055.

1972. Aspects of the distribution of fossil species of calcareous nannoplankton in North Atlantic and Caribbean sediments. Nature, 236:67-70.

Searle, R. C., and Whitmarsh, R. B., 1978. The structure of King's Trough, Northeast Atlantic, from bathymetric, seismic and gravity studies. Geophys. J.R. Astron. Soc., 53:259-287.

Srivastava, S., and Tapscott, C. R., in press. Plate Kinematics of the North Atlantic. In Vogt, P. R., and Tucholke, B. E. (Eds.), Geology of North America: Western Atlantic Region. Geol. Soc. Am. Decade of North American Geology Series, Boulder, CO, Vol. M.

Stebbins, J., and Thompson, G., 1978. The nature and petrogenesis of intraoceanic plate alkaline eruptive and plutonic rocks: King's Trough, Northeast Atlantic. J. Volcanol. Geotherm. Res., 4:333361 .

Takayama, T., 1972. A note on the distribution of Braarudosphaera bigelowi (Gran and Braarud) Deflandre in the bottom sediments of Sendai Bay, Japan. Trans. Proc. Paleontol. Soc. Japan, N.S., 87: 429-435.

Vogt, P. R., and Avery, O. E., 1974. Detailed magnetic surveys in the Northeast Atlantic and Labrador Sea. J. Geophys. Res., 79:363-389.

Whitmarsh, R. B., Ginzburg, A., and Searle, R. C., 1982. The structure and origin of the Azores-Biscay Rise, northeast Atlantic Ocean. Geophys. J.R. Astron. Soc., 70:79-107.

Williams, C. A., and McKenzie, D., 1971. The evolution of the Northeast Atlantic. Nature, 232:168-173.

Date of Initial Receipt: 10 May 1985

Date of Acceptance: 7 May 1986 